\title{
Ovarian steroid hormones: effects on immune responses and Chlamydia trachomatis infections of the female genital tract
}

\author{
LM Hafner ${ }^{1}, K_{\text {Cunningham }}{ }^{1}$ and KW Beagley ${ }^{1}$
}

Female sex hormones are known to regulate the adaptive and innate immune functions of the female reproductive tract. This review aims to update our current knowledge of the effects of the sex hormones estradiol and progesterone in the female reproductive tract on innate immunity, antigen presentation, specific immune responses, antibody secretion, genital tract infections caused by Chlamydia trachomatis, and vaccine-induced immunity.

\section{INTRODUCTION}

A critical function of the unique mucosal immune system of the female genital tract (FGT) is to identify and eliminate potentially pathogenic viral and bacterial agents and to provide protection against sexually transmitted diseases. Globally, it has been estimated that in adults between 15 and 49 years of age there were 105.7 million cases of new Chlamydia trachomatis sexually transmitted infections (STIs) in 2008. ${ }^{1}$ Significant disease sequelae following chlamydial infections of the FGT include pelvic inflammatory disease, tubal infertility, and ectopic pregnancy. ${ }^{2-4}$

The FGT comprises several immune compartments found in the upper genital tract (UGT; endocervix, ovaries, fallopian tubes, and uterus) and lower genital tract (LGT) (ectocervix and vagina). The UGT with Type I mucosa ${ }^{5}$ is lined with a single layer of columnar epithelium and the LGT with Type II mucosa is lined with stratified squamous epithelium (reviewed in Pudney et $\left.a l .{ }^{6}\right)$. The transitional zone where squamous epithelium changes to columnar epithelium is the most immunologically active site of the FGT. Although currently documented (relative) microbial sterility is found in the uterus and fallopian tubes, commensal vaginal flora such as Lactobacillus crispatus are found in the LGT and are under hormonal influences at this site. ${ }^{7}$

The human FGT contains components of the innate and adaptive mucosal immune responses that are found in various distributions at different sites throughout the tract. Figure 1 depicts the FGT anatomy and the location and relative abundances of innate immune cells at this mucosal site. ${ }^{6,8-15}$ In the FGT, the major lymphocyte components are natural killer (NK) cells and $\mathrm{T}$ lymphocytes, including cluster of differentiation (CD) $3+\mathrm{T}$ lymphocytes that are present in all the tissues of the tract. In the LGT, the CD8 + and CD4 + are dispersed throughout the stroma while lymphoid aggregates of these cells are formed in the uterus. ${ }^{16}$ Granulocytes are present and these are principally located in the fallopian tubes. Finally, relative to T lymphocytes, smaller numbers of monocytes and B lymphocytes are found throughout all tissues of the FGT. ${ }^{17}$

Immune cells at this site express both surface and cytosolic pattern recognition receptors (PRRs), including among others Toll-like receptors (TLRs) and the nucleotide-binding oligomerization domain (NOD)-like receptors. TLRs 2 and 4 are highly expressed in the UGT (fallopian tubes and cervix) when compared with expression levels in the LGT (endometrium and ectocervix) while TLRs 7, 8 and 9 and NOD-1 (which is involved in sensing Chlamydia infection) and NOD-2 are expressed at similar levels throughout the tract. ${ }^{18-20}$

In addition to providing a physical barrier for protection, the genital tract epithelial cells (ECs) lining the FGT are immunologically active cells. For example, they act as key initiators of innate and adaptive immunity by secreting cytokines and chemokines, including interleukin (IL)-1b, tumor necrosis factor $\alpha$ (TNF- $\alpha$ ), IL-6, IL-8, and GM-CSF

${ }^{1}$ Infectious Diseases Program, Institute of Health and Biomedical Innovation (IHBI), Queensland University of Technology (QUT), Kelvin Grove, Queensland, Australia. Correspondence: LM Hafner (l.hafner@qut.edu.au)

Received 5 June 2011; accepted 4 June 2013; published online 17 July 2013. doi:10.1038/mi.2013.46 

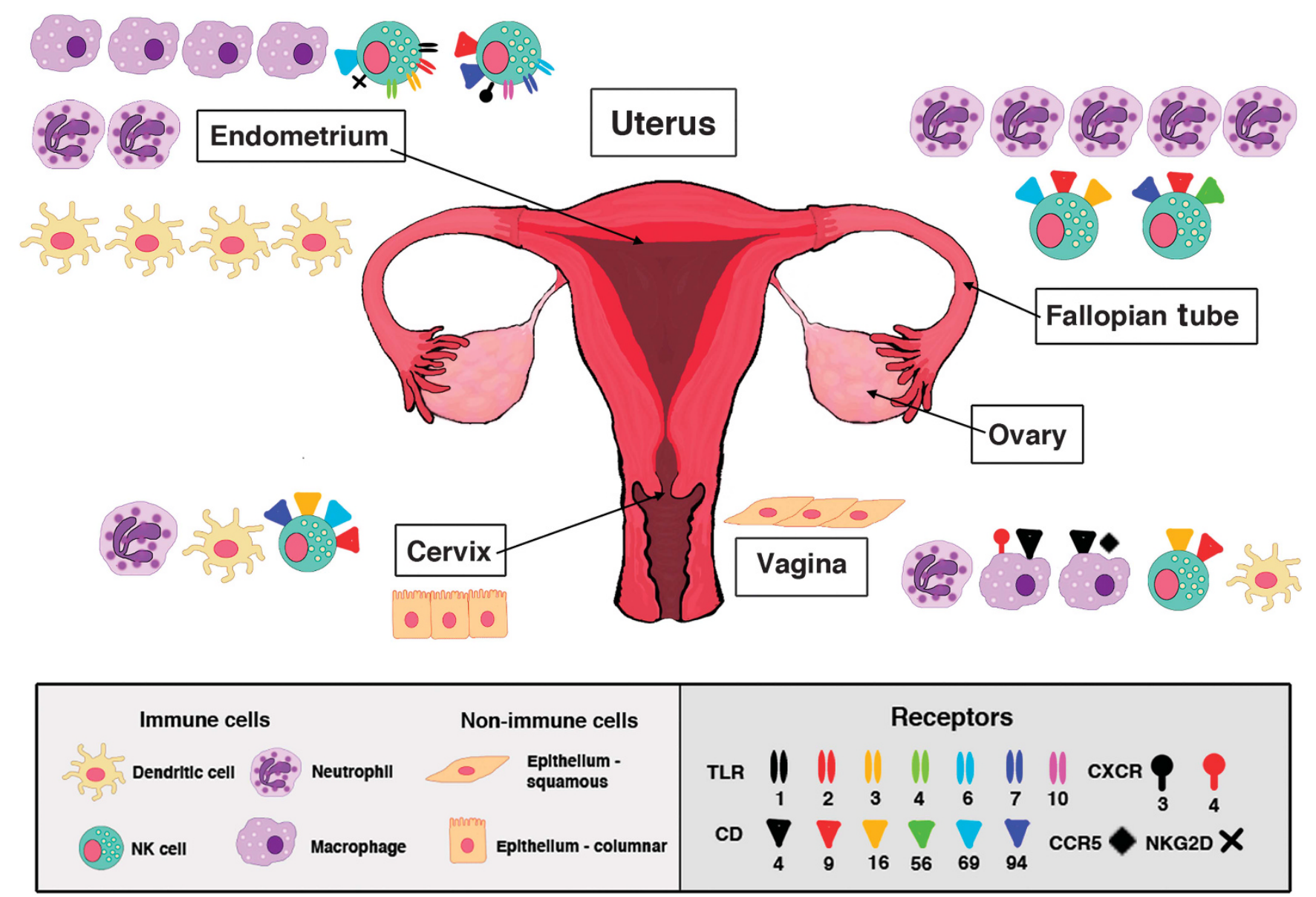

Figure 1 The female genital tract: anatomy and innate immune cells of the genital mucosa. This figure depicts non-immune and innate immune cells found throughout the female genital tract, including macrophages, dendritic cells, neutrophils and natural killer (NK) cells. Immune cell receptors are shown on immune cells. Note that epithelial cell receptors CD4, C-C motif chemokine receptor 5 (CCR5), C-X-C motif chemokine receptor 4 (CXCR4) and GalC on endometrial and endocervical cells are not shown in this figure. TLR, Toll-like receptor; NKG2D, an activating receptor expressed on NK cells that binds to MHC class 1 chain-related protein $A$ and $B$ (MICA and MICB).

(granulocyte-macrophages colony-stimulating factor), in response to human chlamydial infections. ${ }^{21}$

Host protection of the FGT is afforded by two arms of defense comprising innate and acquired immunity. The cellular components of specific immune responses at this site are $\mathrm{T}$ lymphocytes expressing $\alpha \beta$ - and $\gamma \delta$-T-cell receptors (TCR) and immunoglobulins (Igs) producing B lymphocytes. ${ }^{22}$ Effectors of non-specific responses include ECs, monocytes, macrophages, granulocytes (neutrophils, eosinophils, and basophils), dendritic cells (DCs), and NK cells that confer protection due to chemokines, cytokines, and phagocytosis. Cells of both the innate and adaptive immune systems are found in fallopian tubes, uterus, cervix, and vagina. ${ }^{23}$ Localization of T-lymphocyte populations in the female UGT and LGT over the menstrual cycle is summarized in Table $1 .^{10-15,24-40}$

Innate host defense, particularly in the LGT, is provided by the vaginal microbiota maintained in a healthy equilibrium (reviewed in Farage et al. ${ }^{41}$ ) as well as by the myriad of antimicrobial peptides and protease inhibitors of cervicovaginal fluid (Cole ${ }^{42}$ and reviewed in Farage et al. ${ }^{41}$ and Wira et al. ${ }^{43}$ ). The antimicrobial peptides and PRR TLRs are key intermediaries of innate immunity in the FGT. ${ }^{43-46}$
The recruitment and function of immune components of the FGT are precisely regulated by hormonal changes during the menstrual cycle by the sex steroids that co-ordinate cell trafficking and immune activation at this mucosal site. Female sex hormones estrogens, progestins, and androgens are produced by ovarian cells with levels of estradiol (E2 or $17 \beta$-estradiol) and progesterone or P4 (pregn-4-ene3, 20-dione) varying in accordance with fluctuations in the menstrual cycle. ${ }^{22}$ In the menstrual/ovarian cycle of humans, the endometrium develops and follicles grow until ovulation in the Proliferative/Follicular phase. The Secretory/Luteal phase is characterized by high levels of progesterone from the corpus luteum to maintain the endometrium. Finally, corpus luteum regression and menstruation occurs during the menstrual phase. At menstruation, serum E2 levels measure typically $<50 \mathrm{pg} \mathrm{ml}^{-1}$. Gradually, increasing amounts of E2 are found in the follicular (proliferative) phase of the adult female menstrual cycle with serum levels at a pre-ovulatory stage (day 14) ranging from $110-410 \mathrm{pg} \mathrm{ml}^{-1}$ and dropping briefly at ovulation. Levels of E2 (20-160 $\left.\mathrm{pg} \mathrm{mol}^{-1}\right)$ and P4 ( $>5 \mathrm{ng} \mathrm{ml}^{-1}$ ) are present during the luteal (secretory) phase from days $14-28$ of the menstrual cycle typically peaking at day 


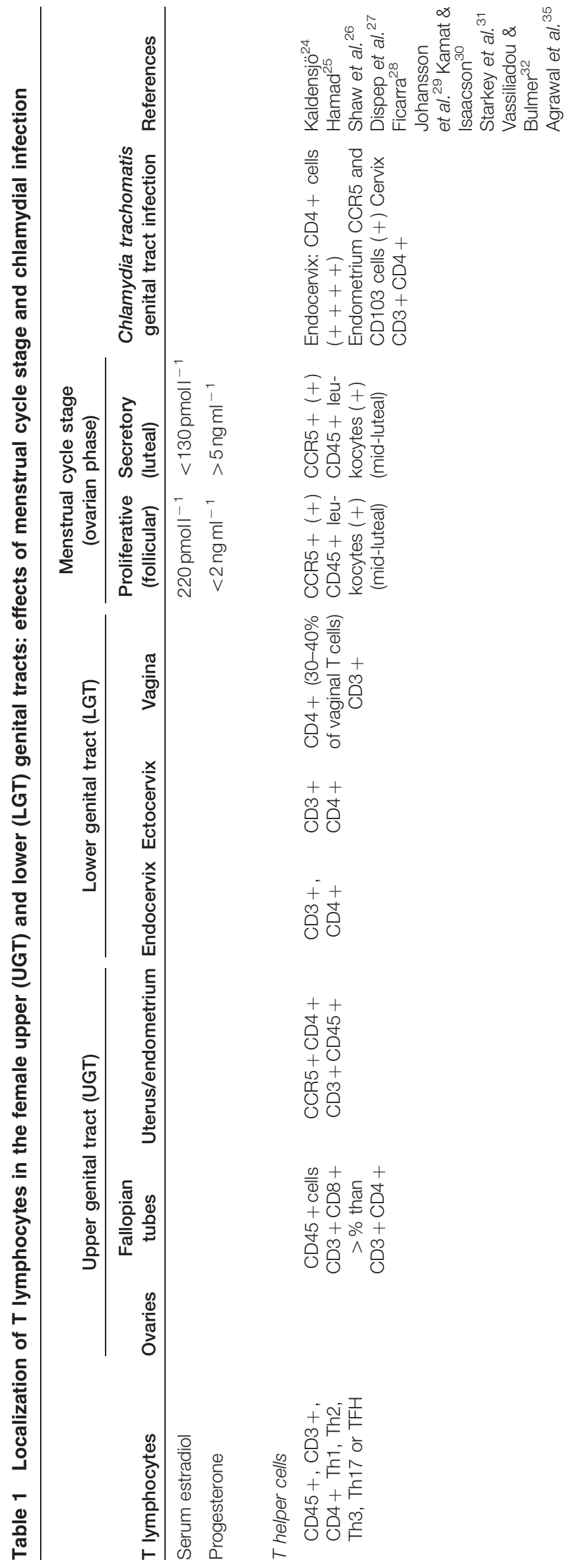

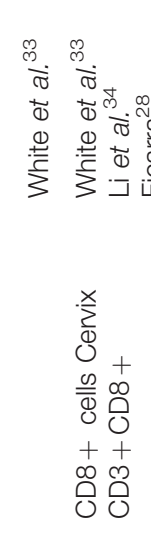

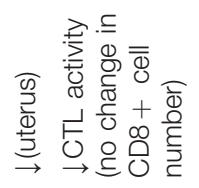

$\frac{\pi}{\frac{0}{2}}$

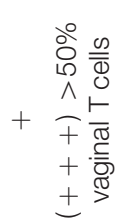

$+$
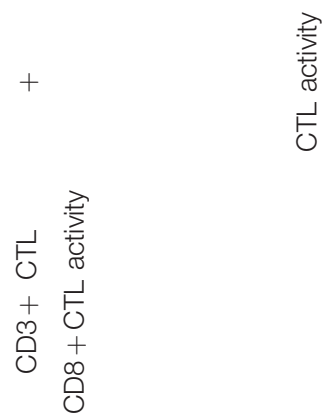

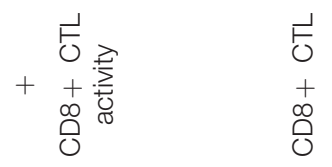

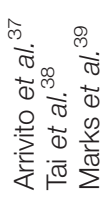
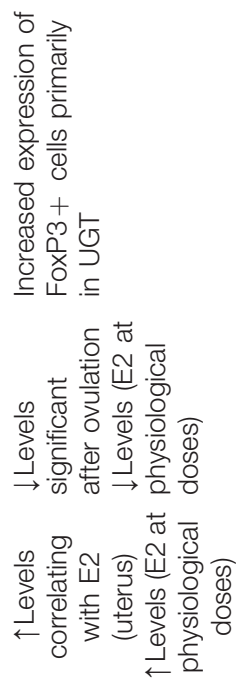

高

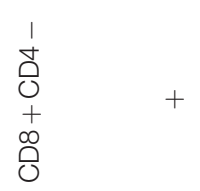

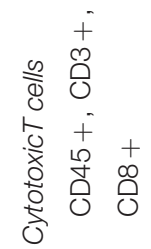

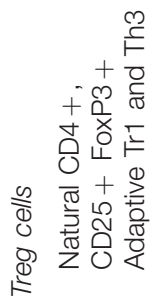




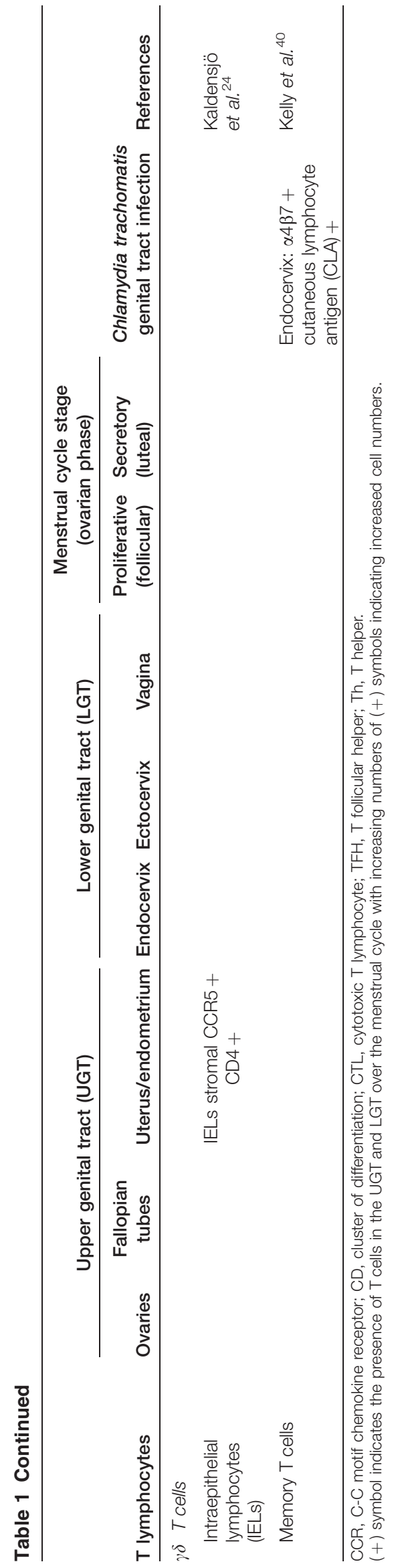

21 of the cycle. At the end of the secretory phase, E2 levels return to their menstrual levels.

The sex hormones E2 and P4 are key contributors to susceptibility and innate and acquired immune responses to bacterial and viral infections of the $\mathrm{FGT}^{47}$ (reviewed in Bouman et al. ${ }^{22}$ Rakasz et al. ${ }^{48}$ and Butts et al. ${ }^{49}$ ). It is also known that these hormones contribute to the sex-based differences both in innate and in acquired immunity and infectious diseases with estrogens affecting levels of chemokine receptors by $\mathrm{T}$ cells and the higher $\mathrm{CD} 4+\mathrm{T}$-cell populations in women undergoing significant changes during the ovarian cycle (reviewed in Fish $^{50}$ ). Differences in E2 levels between male and female mice have also been reported as impacting on the expression of inducible nitric oxide synthase (iNOS) ${ }^{51}$ and hence the production of nitric oxide (NO), a gas that modulates production of pro-inflammatory cytokines, such as IL- 6 and TNF- $\alpha .{ }^{52}$

Innate and adaptive mucosal immunity in the FGT are regulated by the female sex hormones $\mathrm{E} 2$ and $\mathrm{P} 4$ and have been reviewed in Bouman et al. ${ }^{22}$ and Butts and Sternberg. ${ }^{53}$ Hormones regulate the transport of Igs, the levels of cytokines, the expression of TLR genes, ${ }^{54,55}$ and the distribution of immune cells and antigen presentation in the genital tissues during the reproductive cycle ${ }^{23,44}$ Figure 2 depicts the menstrual cycle phases, sex steroid hormone levels, and immune cells present in the FGT.

The afferent and efferent arms of uterine, cervical, and vaginal immune responses are separately regulated and the control by sex hormones is distinct and species-specific in vaginal immune compartments. ${ }^{48}$ In humans, uterus/cervix cellularity and CTL activity is menstrual cycle-dependent with abundant IgA-secreting cells and secretory component expression in the endocervix. In the vaginal immune compartment, cellularity and CTL activity is not menstrual cycle-dependent, $\mathrm{CD} 8+\mathrm{T}$ cells dominate, (and these are vital in a response to chlamydial infection), ${ }^{48}$ there is only a minor population of IgA plasma cells and low levels of secretory component expression, and IgG dominates with peri-ovulatory antibody peaks. ${ }^{48}$

This review summarizes our current knowledge of the effects of sex hormones E2 and P4 in the FGT on innate and adaptive immunity, antibody secretion, genital tract infections caused by C. trachomatis, and on vaccine-induced immunity.

\section{HORMONAL EFFECTS ON INNATE IMMUNITY}

There are many components of innate immunity operational in the vagina and these have recently been reviewed ${ }^{45,56}$ as have components of innate immunity in the ovary and endometrium. ${ }^{57}$ These include soluble factors (such as mannose-binding lectin, complement components, defensins, secretory leukocyte protease inhibitor (SLPI), and nitric oxide), membrane-associated components such as Toll-likedependent and -independent receptors, as well as phagocytic cells. The innate immune system of the FGT is also comprised of many cells, including macrophages, DCs, neutrophils, NK cells, and ECs. It is now becoming increasingly apparent that all aspects of innate immunity, including secretion of protective 


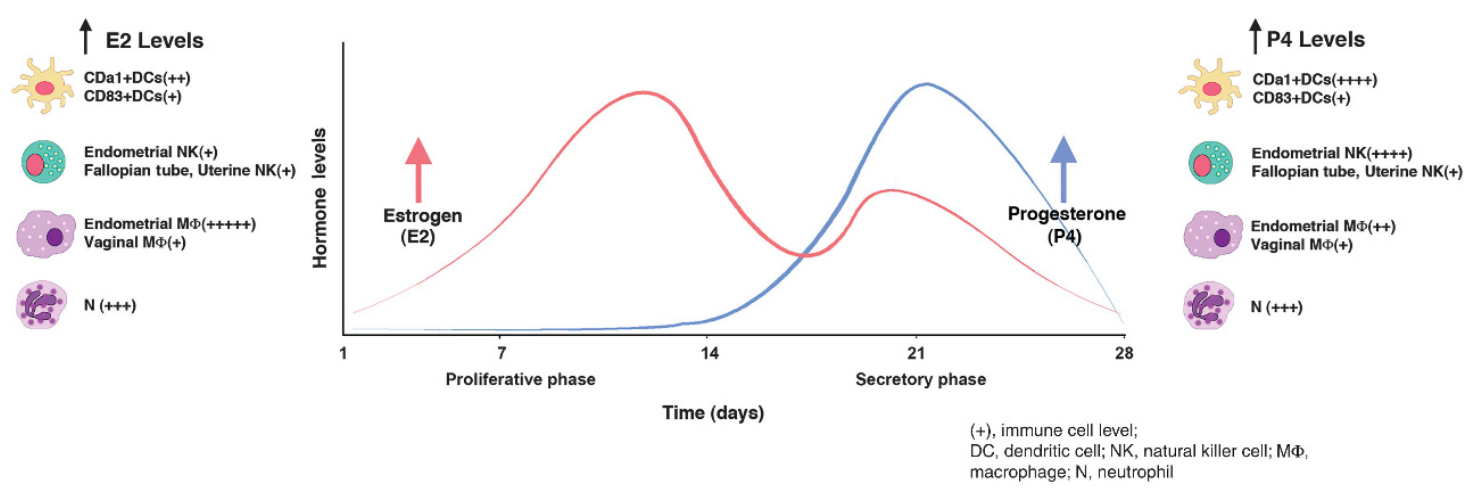

Figure 2 Menstrual cycle phases, sex steroid levels and effects on innate immune cells in the female genital tract. This figure depicts the immune cell types and their relative abundances across the E2 dominant (proliferative) and P4 dominant (secretory) phases of the menstrual cycle.

Table 2 Innate immunity in the human FGT

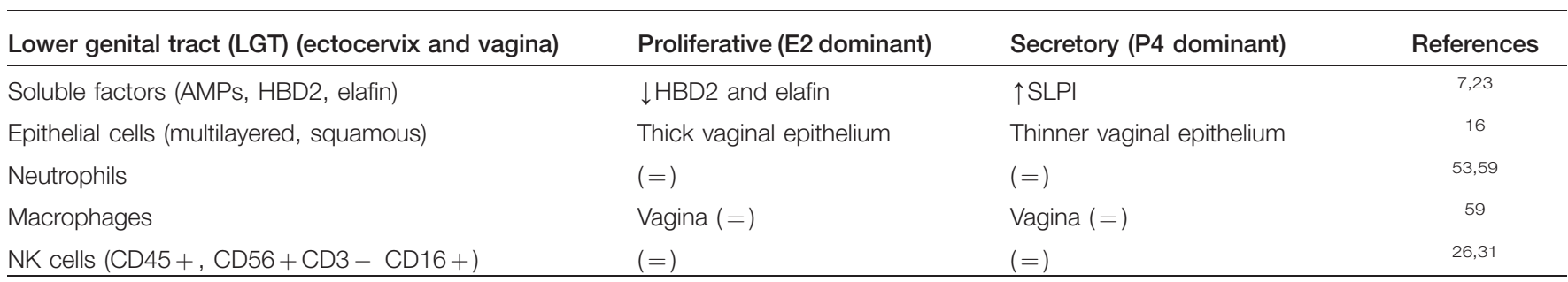

Upper genital tract (UGT) (Endocervix and endometrium, fallopian tubes, and ovaries)

Proliferative (E2 dominant) Secretory (P4 dominant) References

Soluble factors (AMPs, HBDs, elafin)

$\uparrow$ HBD4 (endometrium) (note: HBD2 and elafin peak during menstruation) SLPI and elafin (fallopian tubesconstitutively expressed)

PRRs (TLR, NOD-1, 2)

Epithelial cells (single layer, columnar)

Neutrophils

Macrophages

Dendritic cells

$\mathrm{NK}$ cells CD45 +, CD56 + CD3 - CD16 - , CD69 + $\mathrm{CD} 94+$
TLR10 (fallopian tubes) TLRs

1-7 but not TLR4

(endocervix)

Thick uterine epithelium. Constitutively express IFN- $\varepsilon$ (Type 1 IFN) in luminal and glandular cells highest in the proliferative phase

$\mathrm{CD} 83+(=)$

uNK $\uparrow C T L$ activity

$\uparrow \mathrm{SLPI}, \mathrm{HBD} 1, \mathrm{HBD} 3$ $60-62$ (endometrium) (maximal expression)

TLRs 2, 3 5, 6, 9, including $55,63-68$ TLR4) $\uparrow$ (endometrium), TLR10个(fallopian tubes)

Thin uterine epithelium

Endometrial $\uparrow$

Endometrial $\uparrow$ (before menstruation)

$\mathrm{CD} 1 \mathrm{a}+\uparrow$

Endometrial NK cells (with NKG2D receptor) $\uparrow \mathrm{MICA}$ UNK $\downarrow$ CTL activity via IL-18

AMP, antimicrobial peptide; CD, cluster of differentiation; CTL, cytotoxic T lymphocyte; FGT, female genital tract; HBD2, human $\beta$ defensin 2; IFN, interferon; IL, interleukin; SLPI, secretory leukocyte protease inhibitor; NK, natural killer; NKG2D, an activating receptor expressed on NK cells that binds to MHC class 1 chain-related protein A and B (MICA and MICB); NOD, nucleotide-binding oligomerization domain; PRR, pattern recognition receptor; TLR, Toll-like receptor; UNK, uterine natural killer.

The effects of menstrual cycle phase (proliferative or secretory) on the levels ( $\uparrow$, increased; ( =), constant; or $\downarrow$, decreased) and functions (activity) of innate immune cells, nonimmune cells, and soluble factors.

factors and localization and function of innate immune and non-immune cells, and receptor expression on $\mathrm{ECs}^{58}$ vary with the release of ovarian steroid hormones over the menstrual cycle. Table $2^{7,10-16,23,26,31,40,59-71}$ summarizes the effects of estrogen (E2) and Progesterone (P4) at the proliferative and secretory phases on the aspects of innate immunity in the FGT.
The innate response is triggered by PRRs (including TLRs and non-TLRs such as NOD-like receptors) expressed predominantly by immune effector cells such as macrophages, neutrophils, and DCs that are found in the genital mucosa. These include TLR4 and its co-receptor CD14 (chlamydial lipopolysaccharide (LPS) and heat-shock protein 60 
(HSP60)) ${ }^{72-74}$ TLR2 (chlamydial HSP60), ${ }^{75,76}$ and NOD protein, Nod2 (rudimentary proteoglycan motif produced by C. trachomatis ). ${ }^{77}$ Expression of TLR genes 2-6, 9, and 10 is reportedly significantly higher in human endometrial tissue during the secretory phase (when $\mathrm{P} 4$ is the predominant hormone) compared with all the other phases of the menstrual cycle. ${ }^{47,68}$

The epithelial layer of the vaginal epithelium (LGT) and endometrium, endocervix, and fallopian tubes (UGT) is induced to proliferate producing a thickened uterine epithelium during the proliferative stage of the menstrual cycle when increased secretion of the E2 hormone is observed. During the secretory phase of the menstrual cycle when P4 levels exceed E2 levels, the epithelial layer is reduced in thickness. The human FGT is not as permeable as the rodent FGT to antigen uptake during the P4-dominated secretory phase as P4 does not significantly reduce the thickness of the vaginal epithelium in humans. ${ }^{78}$

\section{Rodent FGT}

In murine models, it has been reported that increased genital infections with $C$. trachomatis are seen in progesterone-treated mice. ${ }^{79}$ Thus the immune responses to chlamydial infections seen in the FGT rodents and humans are likely to be modulated in different ways by these vaginal permeability differences.

\section{HORMONAL EFFECTS ON ANTIGEN PRESENTATION}

In the FGT, sex hormones regulate both antigen presentation by DCs and also the numbers of macrophages and antigenpresenting cells (APCs) found within ECs of uterine and vaginal tissues. ${ }^{80,81}$ Human vaginal tissue contains cells that can present antigen to memory T cells, ${ }^{82}$ and ECs from uterine endometrium are known to constitutively express major histocompatibility complex Class II molecules that are required to present antigen to T lymphocytes. ${ }^{83}$ In the rat, E2 enhances antigen presentation by uterine ECs ${ }^{80}$ whereas in the mouse E2 inhibits EC antigen presentation. ${ }^{81}$ Mature DCs are characterized by high production of IL- $12^{84}$ that facilitates the development of gamma interferon producing Th1 cells. ${ }^{85}$ Estrogen has been shown to modulate the expression of cytokines and chemokines in human monocyte-derived DCs, with mature DCs pre-treated with E2 showing an increased ability to stimulate naive $\mathrm{CD} 4+\mathrm{T}$ cells. ${ }^{86} \mathrm{E} 2$ can therefore regulate DC effector function and can induce and maintain inflammatory responses in the FGT.

The effects of E2 on the differentiation and function of APCs in vitro has been reviewed (see Nalbandian and Kovats ${ }^{87}$ and Butts and Sternberg ${ }^{88}$ ). Much of the current evidence shows that E2 can activate DCs and differentially regulate adaptive immune responses through direct effects on DC functions (see Hughes and Clark ${ }^{89}$ ) via E2 receptor (ER) ligands (reviewed in Kovats and Carreras $\left.{ }^{90}\right)$. It has been shown that ER-alpha (ER $\left.\alpha\right)$ is the main receptor regulating E2-dependent DC differentiation in murine bone marrow-derived DCs in vitro. ${ }^{91}$ At high concentrations typical during pregnancy, E2 plus TNF- $\alpha$ have been reported to induce a distorted maturation of human DCs resulting in an increased capacity to initiate Th2 responses. ${ }^{92}$
P4 has been shown to inhibit many functions of DCs, e.g., suppressing TLR-mediated cytokine production by some subsets of DCs with a recent study focussing on the effect of this sex hormone on TLR signalling in DCs. ${ }^{89}$ These authors state that P4 inhibition of plasmacytoid DC function may impair specific antiviral responses (e.g., HIV or Herpes simplex virus (HSV)-2) that rely on certain TLR subsets and that this inhibition may have a significant impact on global health. P4 is also a potent inducer of semi-mature tolerogenic DCs and is reported to inhibit mature DC activity, which can ultimately contribute to the induction of pro-inflammatory responses. ${ }^{93}$ The effect of sex steroids on the induction and function of a recently described CD4 T-cell subset, Th17 $\mathrm{T}$ cells that are involved in chronic inflammation in some disease states, ${ }^{94}$ is also an area flagged for important future research, as P4-mediated disease remission in autoimmune diseases may involve impaired DC-regulated induction of Th17 cells. ${ }^{89}$ The inhibitory effects of $\mathrm{P} 4$ on immature bone marrow-derived DCs (BMDCs) in female and male rodents has recently been reported to differ and is likely due to differences in $\mathrm{P} 4$ receptor protein expression affecting DC function in these animals. ${ }^{88}$

A recent review of the functions of DCs and subsets of macrophages in the FGT has also addressed the sex hormone regulation of these professional APCs at this mucosal site. ${ }^{95}$ Changes in the populations of DC and macrophage cells in the FGT occur due to (i) varying levels of ovarian steroid hormones at this site, ${ }^{96}$ (ii) the delivery of $\mathrm{CpG}$ oligodeoxynucleotide to the murine genital tract, ${ }^{97}$ and (iii) the stages of the menstrual cycle, noting that the frequencies of macrophages and immature DCs are higher in the menstrual phase when compared with the other phases of the cycle. ${ }^{98,99}$

In a study investigating genital tract infections of C57BL/6 mice with C. trachomatis serovar $\mathrm{D}$, it has been reported that in the LGTs of these mice IL-10 (primarily from CD11b + DC) was the dominant IL, suggesting the presence of Th2 cells in these animals. ${ }^{39}$ In the UGTs of these same animals, a Th1 subset of cells dominated with increased levels of IFN- $\gamma$ expression was recorded following genital tract infections of these mice with $C$. trachomatis. This suggests that DCs are major contributors to IL-10 production in the LGT of mice and that production of this IL likely leads to an anti-inflammatory site of poor Th1 immunity at this mucosal site. ${ }^{39}$

CD16-expressing macrophages and monocytes are also key components of the innate immune system of the FGT and are cells that are capable of producing cytokines and chemokines upon activation. These cells are also known to be profoundly affected by E2 (reviewed in Fish ${ }^{50}$ ). Studies have shown that E2 uses both $\mathrm{ER} \alpha$ and ER beta (ER $\beta$ ) to decrease CD16 expression on monocytes and hence to alter monocytic cytokine release following CD16 receptor activation. ${ }^{100}$ More recently, it has been shown that human macrophages predominantly express an $\mathrm{N}$-terminal truncated variant of $\mathrm{ER} \alpha, \mathrm{ER} \alpha 46$, and that this is also regulated by E2. ${ }^{101}$ Removal of endogenous E2 has been shown to reduce expression of TLR4 on the surface on murine macrophages thus decreasing both pro- and anti-inflammatory cytokine releases from these cells. The addition of exogenous 
E2, however, corresponded with significantly higher expression of cytokines from these cells highlighting the immunoenhancing effects of E2 on these cells. ${ }^{102}$ TLR4-mediated immune responses in macrophages have recently been reported to be inhibited by $\mathrm{P} 4$ via suppression of NF- $\kappa \beta$ activation, suggesting a mechanistic explanation for the regulation of innate immune responses of these cells by this sex hormone. ${ }^{103}$

\section{ROLES OF NON-CONVENTIONAL APCS IN UTERINE AND VAGINAL TISSUES IN INNATE IMMUNITY}

In the FGT, the underlying stromal cells are known to regulate growth and function of polarized ECs, ${ }^{44}$ and uterine stromal cells mediate TNF- $\alpha$ release from uterine ECs in the presence of E2. ${ }^{104}$ It has also been reported that TLRs 1-10 expression levels in murine vaginal ECs were significantly increased during the diestrous phase and expression of TLR2 was significantly decreased in ECs cultured in the presence of stromal cells. ${ }^{105}$

The role of ECs and their associated cytokines in innate immunity of the FGT has been well documented ${ }^{106}$ (reviewed in Quayle ${ }^{9}$ ). Sex hormones regulate the estrous cycle in rodents and the menstrual cycle in women to optimize mating and fertility, and they are also involved in regulating innate immunity in the FGT in both rodents and in mammals. ${ }^{104}$ Human oviduct ECs express TLR 3, and E2 has been reported to suppress the TLR-3-induced cytokine and chemokine production in human endometrial ECs. ${ }^{107}$ Chemokines, including C-C motif chemokine ligand 20/macrophage inflammatory protein $3 \alpha$ (CCL20/MIP-3 $\alpha$ ), have been found to have antimicrobial properties, ${ }^{108}$ and CCL20/MIP-3 $\alpha$ is unique in binding exclusively to CCR6 (chemokine (C-C motif) receptor 6) receptor in humans. ${ }^{109}$ Expression of CCL20/MIP-3 $\alpha$ has been reported from ECs of the FGT, and secretion occurs constitutively as well as being induced by inflammatory conditions. ${ }^{110}$

E2 inhibits IL-1 $\beta$-mediated responses by uterine ECs, suggesting that an inhibitory effect of E2 may be vital for reducing the pro-inflammatory responses that are mediated by these cells. ${ }^{111}$ E2 also can act on endometrial ECs to suppress TLR3-induced cytokines and chemokines. ${ }^{107}$

The effects of $\mathrm{E} 2$ and $\mathrm{P} 4$ on the release of antibacterial factors by ECs in the rat uterus was studied, and it was reported that in ovariectomized rats treated with E2, antibacterial activity against Staphylococcus aureus and Escherichia coli increased in uterine secretions, an effect that was reversed with P4 treatments. ${ }^{61} \mathrm{P} 4$ has been reported to potentiate the E2-stimulated expression of NOS isoforms, including endothelial NOS in endometrial-derived primary and human endometrial surface EC line. ${ }^{12} \mathrm{P} 4$ has also been reported to stimulate the expression of NOS in endometrial ECs, and this may potentially affect infection outcomes at this mucosal site. ${ }^{113}$

\section{HORMONAL EFFECTS ON T LYMPHOCYTES IN THE FEMALE UGT AND LGT}

The FGTs of humans and mice lack underlying organized lymphoid aggregrates, ${ }^{114}$ contrasting with reports of lymphoid cell aggregates in the mucosa of the simian vagina. ${ }^{115}$ Present in the female UGT and LGT are T lymphocytes, specifically $\mathrm{CD} 4+$ and $\mathrm{CD} 8+\mathrm{T}$ cells, along with APCs including macrophages and DCs. Immune mediators of cell-mediated immunity are found distributed within the distinct regions of the female LGT. The cervix is a major inductive and effector site for cell-mediated immunity in the lower human FGT. In women with no current FGT inflammation, macrophages and $\mathrm{CD} 4+$ and $\mathrm{CD} 8+\mathrm{T}$ lymphocytes are most prevalent between the ecto- and endo-cervix, in the so-called cervical transformation zone, and also in the surrounding tissue. Intraepithelial lymphocytes are predominantly $\mathrm{CD} 8+\mathrm{T}$ cells in the cervical transformation zone. The normal vaginal mucosa contains $\mathrm{T}$ cells and APCs with the few immune cells present consisting primarily of $\mathrm{CD} 1 \mathrm{a}+\mathrm{DCs}$ and $\mathrm{CD} 8+$ intraepithelial lymphocytes. ${ }^{116}$ The tissues in the UGT have been found to express a greater number Th1-associated chemokines than the tissues in the LGT comprising the cervical-vaginal region. ${ }^{116}$ The menstrual cycle and menopause have been reported to have no apparent effect on cellular localization or abundance of T-lymphocyte subsets and APCs in any of the LGT tissues. ${ }^{6}$

Migration of T-lymphocyte subsets is vital for adaptive immune responses and is the result of host-pathogen interactions. Effector lymphocytes must be recruited to the FGT after activation in the local iliac lymph nodes. ${ }^{6}$ To eradicate pathogens from the infected genital tract, effector T cells must migrate back to the FGT. ${ }^{6,116}$ Following infection of the mucosal ECs of the FGT, the pathogen induces release of host factors modifying the adhesion cascade. Following chlamydial infection of the murine FGT, increased expression of an adhesion molecule ${ }^{117}$ and expression of Th-1-associated chemokines ${ }^{118}$ has been reported. The release of host factors, in turn, influences the recruitment of lymphocytes to the infection site. These host factors act to modify the specific T-lymphocyte subsets recruited to the FGT in response to infection. In humans, women with cervicitis and vaginitis have been reported to have increased numbers of intraepithelial $\mathrm{CD} 8+$ and $\mathrm{CD} 4+$ lymphocytes and APCs in the vaginal mucosae when compared with women having no symptomatic infections at these mucosal sites. ${ }^{116}$

In mice, investigations into the distribution and function of $\mathrm{T}$ lymphocytes in the FGT have reported that $70-90 \%$ of the lymphocytes in the uterus and upper parts of the cervix of C57BL/ 6 mice are extrathymically derived CD3 $+\alpha \beta T C R+$ CD4-CD8 - T cells. ${ }^{119}$ In the murine vaginal tract, $30-40 \%$ of the $\mathrm{T}$ lymphocytes have been reported as being mostly $\mathrm{CD} 4+\mathrm{T}$ cells (see mini-review by Hamad ${ }^{25}$ ). Hormonal control of cytokine secretion by vaginal and uterine lymphoid cells has been investigated in two strains of mice (Balb/c and $\mathrm{C} 57 \mathrm{BL} / 6$ ), and it was reported that the numbers of IFN- $\gamma$-secreting vaginal and uterine lymphoid cells increased at diestrous in both strains of mice. ${ }^{120}$ Female C57BL/6 mice were also used to show that estrogen-conditioned bone marrow-derived DCs (BM-DC) could enhance regulatory T-cell (Treg) activity and also directly inhibit effector T cells in the absence of Treg cells. ${ }^{121}$ 
In humans, expansion of human CD4 + CD25 + Tregs has been reported to occur in the late follicular (proliferative) phases of the menstrual cycles of fertile women. ${ }^{37}$ This increase in Tregs was correlated not only with normal serum levels of E2 in these women but also with an increased expression of the Foxp 3 gene. ${ }^{38}$ Interestingly, E2 is reportedly responsible for the elevated immune-suppressive potential of Tregs. ${ }^{122}$

Increased expression of FoxP3 + mRNA was seen primarily in the FGT of mice following infections of the genital tracts of these animals with $C$. trachomatis serovar $D{ }^{39}$ It is generally accepted that Treg cell expansion is modulated by E2 ${ }^{37}$ and may be associated with reduced cell-mediated immune responses. Thus it seems that increased levels of P4 during the menstrual cycle (and progestins delivered via hormonal contraceptives) may have profound effects on the outcomes of bacterial infections of the FGT, including those caused by Chlamydia, by increasing Treg freqencies and lowering cell-mediated immunity responses in these infected populations. ${ }^{123}$ Infections of the human FGT with $C$. trachomatis are, however, less likely to occur in P4-dominant conditions. This is due to the fact that, as previously mentioned, the vaginal epithelia of humans is not as permeable to antigen uptake during the P4-associated luteal phase of the menstrual cycle, as $\mathrm{P} 4$ does not significantly thin this mucosal epithelium.

Decreases in the numbers of Tregs have been reported in endometrial samples of 15 progestin-treated patients with atypical endometrial hyperplasia. In these same patients, progestin treatment was associated with significant increases in cytotoxic T-cell activity, suggesting that sub-populations of lymphocytes can be affected by progestins. ${ }^{124} \mathrm{P} 4$ and, to a lesser extent, E2 have both also been reported to reduce Foxp3 + Treg cells in peripheral blood mononuclear cells in in vitro systems that represented the second trimester of human pregnancies. ${ }^{125}$ T-cell activation signalling (by CD3zeta, Janus-associated kinase 2 (JAK2), and JAK3 proteins) and cytokine production in cells exposed to hypoestrogenic $\left(4 \mathrm{pg} \mathrm{ml}^{-1}\right.$ of E2) postmenopausal levels of E2 were shown to diminish significantly, and this correlated with reduced IL-2 production in Jurkat $6.1 \mathrm{~T}$ cells. ${ }^{126}$ This latter finding highlights the fact that a reduction in levels of E2 after menopause can and does contribute to immunosenescence.

T-lymphocyte activity in the human uterus is also influenced by the menstrual cycle; e.g., CD3 $+\mathrm{CD} 8+\mathrm{CTL}$ activity is detectable during the proliferative phase but absent during the secretory (postovulatory) phases of fertile women. ${ }^{33}$ In postmenopausal women, strong CD3 + T-cell cytolytic activity is detected in all compartments of the FGT. These findings suggest that the high levels of E2 and P4 present during the proliferative phase of the menstrual cycle can downregulate CTL activity in the uterus. Studies show that E2 greatly increases the activity of the IFN- $\gamma$ promoter in human T-cell lines, suggesting that E2 may favour Th1 responses. Receptors for E2 have also been shown on both CD8 and CD4 T-cell populations. ${ }^{125}$

Hormonal fluctuations during the estrous cycle that affect cell-mediated immunity in the upper FGT may also potentially have a major part in making this mucosal site distinctively susceptible to chlamydial infections. ${ }^{127,128}$

The FGT of humans and of rodents differs in many ways that can modulate the immune responses at this mucosal site. Both human and rodent genital tracts have large numbers of DCs; however, only the human FGT contains large numbers of $\mathrm{CD} 4+, \mathrm{CD} 8+\mathrm{T}$ cells, B cells, and macrophages. Leukocyte subpopulations are found throughout the human FGT and include T helper cells (Th1, Th2, Th17), cytotoxic T cells, Treg cells, NK cells, and $\gamma \delta \mathrm{T}$ cells. In contrast to rodents, the numbers of $\mathrm{T}$ cells in the vagino-cervix mucosae of women does not change during the various phases of the menstrual cycle. Cytotoxic T-cell activity in the cervix and vagina of women is demonstrated during all phases of the menstrual cycle.

Thus, both the human LGT and UGT are immunologically active throughout the normal menstrual cycles of women. Localization of T-lymphocyte populations in the human female UGT and LGT and the effects of menstrual cycle phases and of chlamydial infections on these immune cells is summarized (Table 1).

\section{HORMONAL REGULATION OF IMMUNOGLOBULIN SECRETION}

In humans, the predominant antibody isotype in female cervicovaginal secretions is $\operatorname{IgG},{ }^{129}$ although secretory $\operatorname{IgA}$ in the polymeric form is also present. ${ }^{130}$ Levels of IgG and IgA antibodies in FGT fluids are modulated by the stage of the menstrual cycle in women and the estrous cycle in rodents.

It is known that the neonatal $\mathrm{Fc}$ receptor, $\mathrm{FcRn}$, in the genital epithelium mediates transport of IgG into the FGT and that local levels are affected by stage of the murine estrous cycle, with highest levels being recorded at diestrous. ${ }^{131}$ The transport of IgG into the fallopian tubes and uterus is also significantly decreased by $\mathrm{P} 4$ treatment, and this is likely correlated with FcRn expression. ${ }^{132}$

Mucosa-associated epithelial chemokine CCL28 can recruit IgA plasma cells to the uterus of the murine reproductive tract following mucosal (intranasal or vaginal) immunizations, and this migration is dependent upon E2. ${ }^{133}$ Interestingly, the IgA plasma cells induced by mucosal vaccination were recruited to the uterus but not to the cervix or the vaginal canal. E2 also upregulates the in vitro expression in the FGT of secretory component increasing transport of IgA into the lumen, ${ }^{134}$ and transport of polymeric IgA (pIgA) into FGT tissues is significantly decreased by ovariectomy, although this decline can be reversed by the addition of E2 but not of P4. ${ }^{132}$

The levels of Igs in genital tract secretions of women vary during the menstrual cycle, with the lowest levels of IgG occurring around the time of ovulation in women with human papillomavirus (HPV)-16 vaccine-specific antibodies with total IgG and IgA titers in cervical fluid highest in the proliferative phase of the cycle. ${ }^{135,136}$ In normal cycling female macaques, it has been reported that the frequency of Ig-secreting cells (ISC) was significantly higher in tissues collected from animals in the peri-ovulatory period of the menstrual cycle than in tissues collected from other stages of the 
cycle and that this effect was apparently due to the action of estrogen on CD8 $+\mathrm{T}$ cells. ${ }^{137}$ The effects of ovarian hormones on (ISC) function in healthy women were also investigated, and it was reported that ISC frequency in PMBC was highest during the peri-ovulatory stage of the menstrual cycle. ${ }^{138}$

In murine studies, not surprisingly, it has been shown that E2 influences Ig levels in post-pubertal female C57BL/6 (B6) mice, with these animals expressing genes involved in adaptive immune responses, including IgA, IgG1, IgG2, and B-cell receptor gene involved in $\mathrm{B}$-cell signalling. ${ }^{139}$ In female $\mathrm{BALB} / \mathrm{C}$ mice, E2 strongly stimulated the production of bovine serum albumin (BSA)-specific antibodies (mostly of the IgG1 isotype) in the sera of BSA-immunized mice. ${ }^{140}$ A study of the effects of sex hormones on migration of antibody-secreting cells into the genital tracts of female $\mathrm{BALB} / \mathrm{c}$ mice revealed that the mRNA expression from adhesion molecules and chemokines intercellular adhesion molecule 1, P-selectin, and JAM-1 (junctional adhesion molecule 1) was significantly increased in ovariectomized mice and that these changes were restored to normal levels by E2 treatment. ${ }^{141}$

The maturation, selection, and activation of B cells is also known to be affected by estrogen treatment, with E2 shown to alter the later stages of B-cell development (reviewed in Grimaldi et al. ${ }^{142}$ ). Recently, it has been reported that in female B-cell-deficient mice that do not express IgM, E2 increased the frequency of IgA-producing plasma cells, suggesting that $\mathrm{E} 2$ can influence an alternative B-cell pathway found in these mice. ${ }^{143}$

IgA-secreting plasma cells typically produce dimeric IgA (dIgA), and once secreted into the lamina propria, dIgA binds the polymeric Ig receptor (pIgR) at the basolateral surface of mucosal ECs forming secretory IgA. It is known that dIgA:pIgR complexes can neutralize intracellular pathogens such as $\mathrm{HIV},{ }^{144}$ although the precise effects of these complexes on chlamydial infections is presently unknown. The pIgR is ubiquitously expressed by ECs in the human FGT, with high expression observed in the UGT. ${ }^{145}$ Innate (mediated by TLR3) and adaptive immune responses (including IFN- $\gamma$ ) to infection are known to regulate pIgR expression. Additionally, the sex hormones E2 and P4 also have regulatory roles in the expression of pIgR. In female rats, E2 is known to upregulate the pIgR expression, ${ }^{146}$ although in primates ovulation coincides with a decrease in mucosal antibodies. ${ }^{134}$ The sex hormone P4 downregulates pIgR expression in rats, ${ }^{147}$ and although the specific role of the pIgR in chlamydial infections is debatable, the protective role of IgA and the pIgR may indeed be of importance in the development of subunit vaccines against C. trachomatis.

\section{SEX HORMONES AND GENITAL TRACT INFECTION}

It is becoming increasingly well documented that sex hormones E2 and P4 regulate host susceptibility, as well as innate and adaptive immune responses, to sexually transmitted pathogens infecting the mucosal surfaces of the FGT. STD pathogens that infect this site include viruses (HIV-1, HSV-2, HPV) and bacteria such as Neisseria gonorrhoeae and C. trachomatis.
There are numerous reports in the literature on studies in women and in animal models that report the effects of sex hormones on genital tract infections caused by these mucosal pathogens (e.g., for HIV review, see Hel et al. ${ }^{148}$ ).

In this review, we will specifically focus our discussions on C. trachomatis as this organism is the perennial target for much of our own research.

\section{C. trachomatis}

The columnar ECs of the FGT are target cells for chlamydial infection, and although natural immunity to infection with this mucosal pathogen does occur, it is serovar-specific and short-lived. Local host defence against Chlamydia involves the mucosal barrier comprised of ECs and mucus and innate, humoral, and cell-mediated immune responses (Figure 3). Decreased levels of SLPI in vaginal secretions are reportedly inversely related to infections caused by C. trachomatis, ${ }^{149}$ but SLPI expression is reportedly induced following C. trachomatis infection of the $\mathrm{FGT}^{150}$ and elafin mRNA expression is upregulated in a Chlamydia-infected oviduct EC line ${ }^{62}$ (see Table $3^{150-153}$ ).

Infection of the FGT with live replicating C. trachomatis is innately recognized by surface PRRs TLR2 and TLR4 that are highly expressed in the UGT tissues. ${ }^{45}$ The myeloid differentiation primary response gene $(\mathrm{MyD}) 88$ is essential for nuclear factor- $\kappa \beta$ (NF- $\kappa \beta)$ signalling and transcription of proinflammatory cytokines. Along with TLR2, MyD88 specifically co-localizes with the intracellular chlamydial inclusion. ${ }^{154}$ Additional to the TLRs the NOD-like receptor, NOD1, also senses chlamydial infection of endocervical ECs. Signals transduced from these TLRs lead to induction of IFN- $\gamma$ and cytokine genes that contribute to resolving chamydila genital infection in an IFN- $\gamma$-dependent manner, noting also that TLR2 is also responsible for severe tubal immunopathology in a murine model and that the chlamydial plasmid has a crucial role in TLR2 activation. ${ }^{155,156}$ In response to chlamydial infection, ECs secrete pro-inflammatory cytokines/chemokines such as IL-6 and IFN- $\gamma$ that are hypothesized activators of pathology in the cellular paradigm of chlamydial pathogenesis. ${ }^{157}$

C. trachomatis infection of the female LGT stimulates innate immune cells by activation of TLR2/TLR4 (reviewed in Schaefer et al. ${ }^{158}$ ). TLRs 2 and 4 have been found at the highest expression levels in endometrium and fallopian tube tissue, ${ }^{159}$ with the predominant expression of TLR4 and its co-receptor CD14 in the fallopian tubes proposed to have an important role in the innate host defence mechanism against ascending C. trachomatis infections. ${ }^{158,160}$ In a recent study, C. trachomatisinfected women have been reported to express higher TLR2, TLR4, and iNOS in their cervical monocytes compared with controls. It is thought that TLR4 initiates the innate immune response to chlamydial infection, activation of TLR2 leads to expression of inflammatory cytokines while iNOS contributes to chlamydial clearance from this mucosal site. ${ }^{161}$

Studies into C. trachomatis infections of the FGT have reported many effects of hormones on infection and immunity 


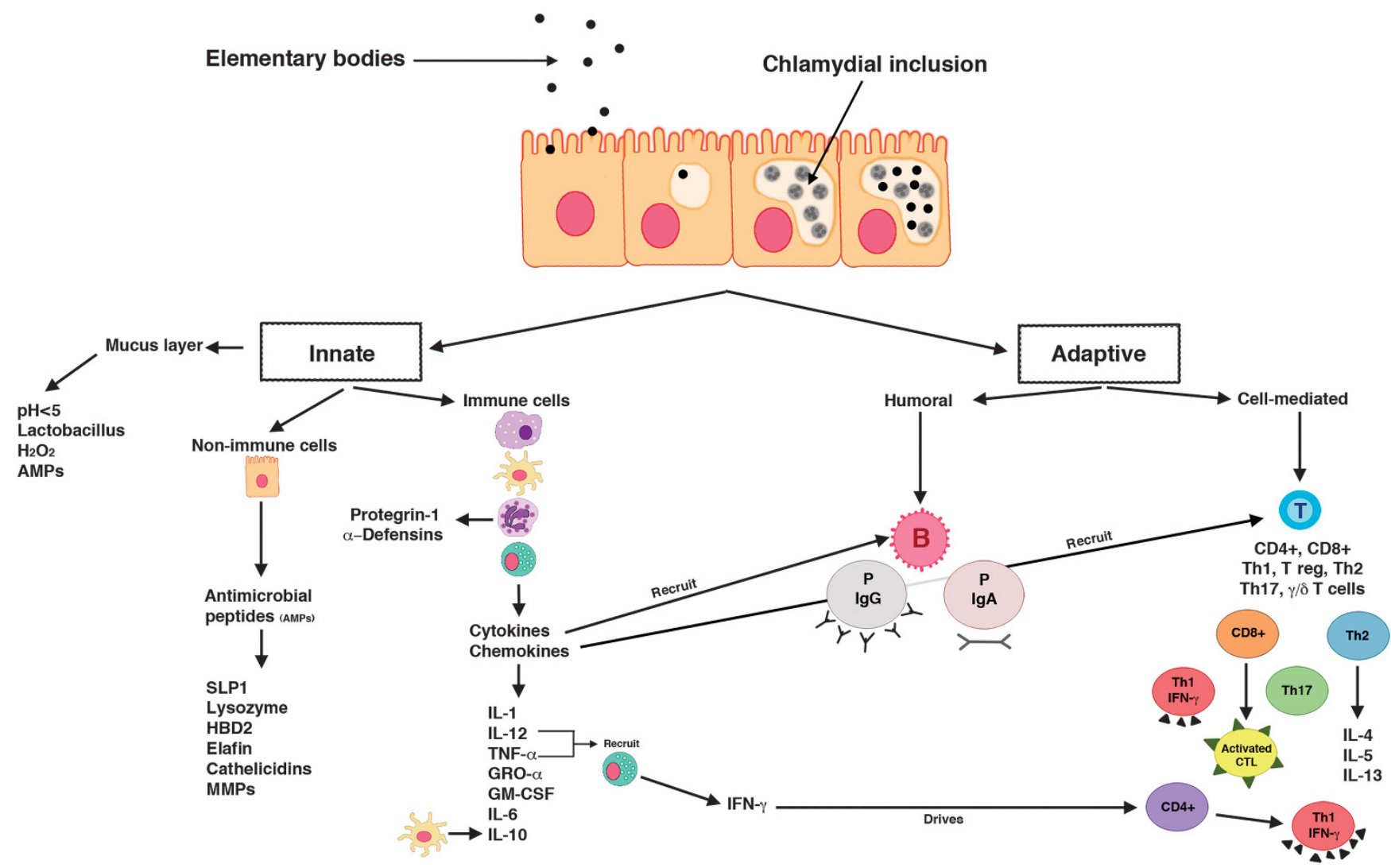

Figure 3 Immune protection against chlamydial infection in the female genital tract. Innate, humoral, and cell-mediated immunity act in concert to protect against $C$. trachomatis infection of non-immune host genital epithelial cells and local innate immune cells in the female genital tract. The hormones estradiol and progesterone regulate innate and adaptive immunity against genital Chlamydia by promoting mucus secretions, regulating immune and non-immune cell numbers and activities (Figure 2), and by altering cell receptor expression at this mucosal site. Innate: The epithelial barrier is relatively ineffective at protecting against Chlamydia as this mucosal pathogen has a myriad of mechanisms to evade barrier protection. A mucus layer containing a variety of antimicrobial factors and endogenous microbiota contributes towards regulating the $\mathrm{pH}$ of the FGT to protect against genital tract pathogens. Innate immune cells constitutively secrete an array of soluble antimicrobials, including secretory leukocyte protease inhibitor (SLPI), human $\beta$-defensin 2 (HBD2), lysozyme, lactoferrin, Elafin, cathelicidins. Chlamydial infection of columnar epithelial cells and local genital tract immune cells, including neutrophils, macrophages, and natural killer (NK) cells, produces soluble antimicrobials,chemokines, and pro-inflammatory cytokines that selectively prevent bacterial infection of target host cells. (e.g., interleukin (IL)-1 released from infected epithelial cells promotes T helper type 17 (Th17) differentiation). Recruitment and activation of adaptive immune cells (B and T cells) are also orchestrated by the release of these secreted soluble antimicrobial factors from epithelial cells, dendritic cells, and macrophages. Humoral: Antibodies potentially can prevent infection by Chlamydia. Immunoglobulin $G(\lg G)$ is the predominant antibody in the FGT. Antibodies released from plasma cells ( $P \lg G$ and $P \lg A)$ inactivate extracellular chlamydial elementary bodies. Cell-mediated: CD4 + T-cell production of interferon (IFN)- $\gamma$ contributes to host defence by inhibiting intracellular chlamydial replication. Cell-mediated immunity induces apoptosis of infected cells by cytotoxic CD8 + T cells. $6,20,35,39,40,62,63,77,117-119,150-157,172$ CTL, cytotoxic T lymphocyte; GM-CSF, granulocyte-macrophages colony-stimulating factor; MMP, matrix metalloproteinase; GRO- $\alpha$, growth related oncogene- $\alpha$; TNF, tumor necrosis factor; Treg, regulatory T cell.

to the pathogen at this mucosal site. For example, significant increases in the sensitivities of cervical ECs to infection with C. trachomatis occur in the later stages of the female menstrual cycle. $^{162}$ It has been reported that chlamydial infection occurring in the early E2-dominant phases of the cycle was a significant predictor for development of salpingitis. ${ }^{163}$ Clinical findings have also reported on the enhancing effects of E2 on chlamydial infection and disease sequelae in the infected FGT. It has been reported that women are more susceptible to chlamydial infection under the influence of E2. ${ }^{35}$ In women with fertility disorders $(n=115)$ and in women with C. trachomatis mucopurulent cervicitis $(n=86)$, a significantly positive correlation was recorded between chlamydial load and E2 levels. ${ }^{21}$
Hormones can also affect the immune responses to chlamydial infections of the FGT in mice. A recent seminal study has reported that IFN- $\varepsilon^{-{ }^{-}}$mice showed significantly increased levels of chlamydial growth in the UGTs at 30 days post intravaginal infection with C. muridarum. The mice also showed more severe clinical signs of disease following intravaginal infections with sub-lethal doses of $C$. muridarum. IFN- $\varepsilon$ expression is also hormonally regulated. The presence of high levels of E2 (proliferative phase) coincided with the highest expression levels of IFN- $\varepsilon$, and E2 administration to ovariectomized mice induced a six-fold increase in IFN- $\varepsilon$ expression. Thus, IFN- $\varepsilon$ constitutively expressed by luminal and glandular ECs of the endometrium can protect against Chlamydia without aggravating disease-the first report that 
Table 3 Chlamydia trachomatis and antimicrobial peptides (AMPs)

\begin{tabular}{|c|c|}
\hline Study & Experimental findings \\
\hline \multicolumn{2}{|c|}{ Chlamydia stimulates AMP expression } \\
\hline King et al. ${ }^{62}$ & $\begin{array}{l}\text { In vitro-infection of oviductal epithelial cell line results in } \\
\text { increased elafin expression but no effect on SLPI }\end{array}$ \\
\hline $\begin{array}{l}\text { Wheelhouse } \\
\text { et al. }{ }^{150}\end{array}$ & $\begin{array}{l}\text { In vitro-infection of HeLa (cervical epithelium) and JEG- } \\
3 \text { (trophoblast) cells results in increased SLPI expression }\end{array}$ \\
\hline
\end{tabular}

AMP activity against Chlamydia

Pal et al. ${ }^{151}$ In vivo-MMP-7 knockout mice (with reduced $\alpha$-defensin activity) were unaffected in their ability to clear chlamydial infection

Oberley In vitro-surfactant protein D protein inhibits the infection et al..$^{152}$ of HeLa cells (an endocervical epithelial cell line by $C$. trachomatis

Yasin et al. ${ }^{153}$ In vitro-rabbit defensin (NP-1), HNP-2, and porcine leukocyte Protegrin reduced chlamydial infection

HNP-2, human neutrophil peptide 2; JEG-3, human placental choriocarcinoma cell line; MMP-7, matrix metalloproteinase 7; NP-1, neutrophil peptide 1; SLPI, secretory leukocyte protease inhibitor.

indicates a Type 1 interferon can protect and not worsen a chlamydial genital tract disease. ${ }^{69}$

Chemokine receptors direct $\mathrm{T}$ lymphocytes to the site of mucosal infection, including infection of genital tract ECs with C. trachomatis, and these receptors can be modulated by E2. In a study examining samples from human patients, it was reported that CCR5 expression increased followed C. trachomatis genital infections. ${ }^{28}$ It is also now known that CXCR3 (chemokine (C-X-C motif) receptor 3) and CCR5 are the predominant receptors that are crucial for T-lymphocyte access to the genital tract during a $C$. trachomatis infection in a murine model. ${ }^{164}$ Therefore, the protective capacity of Chlamydia-specific T cells in the genital tract can be modulated by the sex steroid E2.

Reproductive hormones may potentially act with cytokines to regulate immune responses in the FGT to chlamydial genital tract infections in vivo. Significant negative correlation has been reported between $\mathrm{E} 2$ levels in women with primary chlamydial genital infections and cervical wash concentrations of IL-10, IL- $1 \beta$ and IL- 6 cytokines. Significant negative correlation was also recorded between IL-1 $\beta$ cytokines and P4 levels in women with recurrent chlamydial infections. ${ }^{165}$ Thus it would appear that chlamydial infection of the human FGT is modulated, in part, by the combined actions of cytokines with E2 and P4. More recent investigations reveal that levels of E2 were significantly higher in Chlamydia-positive women with fertility disorders when compared with fertile women, suggesting that this sex hormone contributes to the development of disease sequelae to $C$. trachomatis infection of the FGT. ${ }^{35}$

Results of studies into the course of genital chlamydial infections in animal models have also revealed the effects of reproductive hormones on immune responses and disease sequelae. Results of these studies have validated much of the clinical data for chlamydial genital infections in women. In mice, significantly more chlamydiae were recovered from the uterine horns and oviducts when animals were infected during periods of increased levels of $\mathrm{P} 4$ and E2 (secretory phase) rather than when infections occurred during the follicular phase. ${ }^{166}$ Rank et al. ${ }^{127}$ reported that high E2 levels in guinea pigs corresponded with a significantly greater percentage of Chlamydia-infected animals developing oviduct pathology. It was also reported that high doses of $\mathrm{P} 4 \mathrm{did}$ not alter the course of genital infection in guinea pigs, ${ }^{128}$ but other reports using different animal models showed that these doses increased the rate of infection, e.g., using a rat model ${ }^{167}$ and also that high doses of $\mathrm{P} 4$ resulted in more intense C.muridarum infections of mice. ${ }^{168}$

Attachment and infectivity of chlamydial elementary bodies in vitro reportedly has been enhanced by E2 for HeLa cells, ${ }^{169}$ human endometrial ECs, ${ }^{170}$ luminal ECs from swine genital tracts, ${ }^{171}$ and oestrogen-responsive endometrial carcinoma cell lines Ishikawa and HEC1B and breast cancer lines. ${ }^{172}$ In vivo, ECs have been reported to be more sensitive to $C$. trachomatis serovar E in the E2-dominant (proliferative) stage of the human menstrual cycle than at other stages of the cycle. ${ }^{173,174}$ More recently, preliminary work from our own laboratory has investigated infection of ECC-1 human endometrial cell lines with C. trachomatis serovars D and L2 supplemented with $200 \mathrm{pg} \mathrm{ml}^{-1} \mathrm{E} 2$ or $20 \mathrm{ng} \mathrm{ml}^{-1} \mathrm{P} 4$. We report that P4 upregulates adhesion molecules involved in cell recruitment (CX3CL1, E-selectin, ITGB8, and others) and downregulates IFN and IFN receptor genes. Our results indicate that the gene expression patterns induced by E2 in this system are suggestive of persistent chlamydial infection. ${ }^{175}$

Hormonal contraceptive use in women, particularly depo medroxyprogesterone, has also been reported in observational studies to be associated with a fourfold increase in chlamydial genital tract infections, ${ }^{176}$ although the biological explanation for increased risk of infections caused by depo medroxyprogesterone has been challenged. ${ }^{177}$ A feasibility plan recently has been conducted to pave the way for a future randomized trial to investigate hormonal contraception and the risks of STI acquisition in women. ${ }^{178}$

Thus in terms of developing a protective mucosal vaccine for Chlamydia, it is, therefore, prudent to consider the influences of sex hormones on infection and immune responses to C. trachomatis within the FGTs both of humans and of animals.

\section{SEX HORMONE INFLUENCE ON VACCINE-INDUCED IMMUNITY}

Many studies examining the effects of sex hormones on vaccine-induced immunity against sexually transmitted pathogens have been conducted using the murine model with animals that undergo an estrus cycle. The cycle consists of Proestrus and Estrus, in which follicles grow and mature, the endometrium develops, and an estrogen surge occurs in conjunction with ovulation. In Metestrus, the corpus luteum and high levels of progesterone are seen, and during Diestrus the corpus luteum regresses. In estrus, it is also seen that the endometrium is reabsorbed if conception does not occur while 
in the human menstrual cycle the endometrium is shed. It is to be noted, however, that with respect to chlamydial infections of the FGT there are many differences between the murine models using C. muridarum and the pathogenesis of human C. trachomatis endocervical infections. Two examples of these differences are (i) the strain of Chlamydia used in the mouse model, which is not a natural pathogen of the murine FGT, and (ii) Th1 immunity to C.muridarum in the mouse model that causes significant damage to the UGTs of mice while in endocervical infections of women with $C$. trachomatis UGT damage occurs infrequently.

When $\mathrm{E} 2$ prevents the penetration of antigen into the vaginal epithelium by increasing the mucosal barrier thickness, it reduces the antigen-loading of vaginal APCs. E2 thus inhibits the crucial process of $\mathrm{CD} 8+\mathrm{T}$-cell priming, although antigen uptake can still occur in the vaginal mucosa following removal of the mucus layer at this site. Interestingly, when antigen is administered orally or intranasally during the E2-dominant phases of the estrus cycle, specific antibodies in the FGT are significantly enhanced. ${ }^{179}$ The ability to prime CD $8+\mathrm{T}$ cells after immunization at the progesterone-treated genital tract is strongly influenced by ovarian steroid hormones. ${ }^{180}$ Thus, it needs to be remembered that sex steroids can modulate immune responses following intravaginal and intranasal routes of immunization, routes that are more effective at eliciting genital tract antibody responses than parenteral immunization.

Song et al. ${ }^{181}$ investigated the effects of exogenous E2 administration, following intravaginal inoculation of $\mathrm{BALB} / \mathrm{c}$ mice with $N$. gonorrhoeae, and they found an increase in gonococcal-specific serum antibody in these animals. Others have found that E2 treatment increased the specific antibody response to Dinitrophenyl-keyhole limpet hemocyanin (DNP-KLH), a T-cell-dependent antigen, in BALB/c mice. By experimenting with agonists to each of the ERs (ER $\alpha$ and ER $\beta$ ), they determined that the effects of E2 on antibody production are mediated via signalling pathways involving both ER receptors. ${ }^{182}$ It appears that the timing between E2 administration and immunization or challenge doses can affect the ability of the antigen/micro-organism to penetrate the mucosal epithelia; choice of mouse strain may also affect these processes.

Protection against several STIs, including C. trachomatis, requires not only the stimulation of $\operatorname{IgG}$ and IgA antibodies but also antigen-specific CD4 $+\mathrm{T}$ cells in the genital tract. However, our knowledge is rudimentary regarding both T-cell responses to the effects of sex steroids following mucosal immunizations to induce these responses in the FGT. A recent study investigating live chlamydial genital tract infections in the murine model reported that $\mathrm{P} 4$ is required for an effective, protective T-cell response in the genital tract following intravaginal immunizations but that E2 prevented a response. ${ }^{39}$ Thus CD $4+$ T-cell immunity in the FGT can indeed be induced by local mucosal immunization with appropriate chlamydial immunogens (e.g., major outer membrane protein) and adjuvants (e.g., CTA-DD) as has recently been reported. ${ }^{183}$ Optimal protection at this site will require knowledge of the ovarian steroid status at the time of immunization in attempts to elicit protective immunity against a live genital tract infection with Chlamydia.

In non-human primates, studies have shown that live attenuated lentivirus (simian-human immunodefiency virus) protects $60 \%$ macaques against challenge with intravaginal simian immunodeficiency virus. Depo-provera pre-treatment of the animals resulted in a decrease in this protection, ${ }^{184}$ a finding that is similar to that observed in mice.

Finally, only a limited number of studies to date have examined the effects of sex hormones on vaccination outcomes in females. Women who were given vaginal immunizations with bacterial LPS during either the E2-dominant follicular or the P4associated luteal phases of the ovarian cycle only induced cervical IgA2-restricted antibodies against LPS when immunized during the follicular phase of the cycle. ${ }^{185}$ Women who were given intravaginal immunizations with a recombinant Cholera toxin $B$ subunit and immunogen showed no differences in their resulting immune responses to the antigen whether they were using P4containing intra-uterine devices, on the oral contraceptive pill, or were using no contraception at all. ${ }^{186}$ These results indicate that the magnitude of the immune responses elicited in the FGT could be influenced by the phase of the menstrual cycle for intravaginally administered vaccines.

\section{SUMMARY}

The FGT is a site of abundant immune processes having an extensive lymphoid system capable of mounting a protective immune response to intracellular pathogens, such as C. trachomatis. The effects of ovarian steroid hormones on innate immunity, antigen presentation, T-cell-specific immunity, and Ig production have been examined with some studies that have been highlighted presenting contradictory findings to other studies discussed. The contrary reports are likely due to the variety of cell lines and models used in the experimental investigations and also due to varying levels and combinations of hormones tested in these studies.

This review highlights and updates our current knowledge of the effects of ovarian steroid hormones on various components of immune responses in the FGT and how these responses can modulate susceptibility of this mucosal site to STIs. Future investigations into vaccines to control infections of the female reproductive tract will need to consider the effects both of E2 and of $\mathrm{P} 4$ at this mucosal site. Animal models and in vitro assays should continue to be refined in design with respect to sex hormone status in attempts to more accurately reflect the potential efficacy of novel vaccine preparations tested in these models that are destined for use in humans.

\section{ACKNOWLEDGEMENTS}

Australian National Health and Medical Research Council (NHMRC).

\section{DISCLOSURE}

The authors declared no conflict of interest. 


\section{REFERENCES}

1. World Health Organisation (WHO) Global Incidence and Prevalence of Selected Curable Sexually Transmitted Infections-2008. World Health Organisation, Geneva, Switzerland, 2012.

2. Farquhar, C.M. Ectopic pregnancy. Lancet 366, 583-591 (2005).

3. Mardh, P.A. Tubal factor infertility, with special regard to chlamydial salpingitis. Curr. Opin. Infect. Dis. 17, 49-52 (2004).

4. Agrawal, T., Vats, V., Salhan, S. \& Mittal, A. Tubal factor infertility, with special regard to chlamydial salpingitis. J. Reprod. Immunol. 83, 173-178 (2009).

5. Woodrow, K.A., Bennett, K.M. \& Lo, D.D. Mucosal vaccine design and delivery. Annu. Rev. Biomed. Eng. 14, 17-46 (2012).

6. Pudney, J., Quayle, A.J. \& Anderson, D.J. Immunological microenvironments in the human vagina and cervix: mediators of cellular immunity are concentrated in the cervical transformation zone. Biol. Reprod. 73, 1253-1263 (2005).

7. Keller, M. et al. PRO2000 elicits a decline in genital tract immune mediators without compromising intrinsic antimicrobial activity. AIDS 21, 467-476 (2007).

8. Johansson, M. \& Lycke, N.Y. Immunology of the human genital tract. Curr. Opin. Infect. Dis. 16, 43-49 (2003).

9. Quayle, A.J. The innate and early immune response to pathogen challenge in the female genital tract and the pivotal role of epithelial cells. J. Reprod. Immunol. 57, 61-79 (2002).

10. Givan, A.L. et al. Flow cytometric analysis of leukocytes in the human female reproductive tract: comparison of fallopian tube, uterus, cervix, and vagina. Am. J. Reprod. Immunol. 38, 350-359 (1997); http:// www.ncbi.nlm.nih.gov/pubmed/9352027.

11. King, A., Wellings, V., Gardner, L. \& Loke, Y.W. Immunocytochemical characterization of the unusual large granular lymphocytes in human endometrium throughout the menstrual cycle. Hum. Immunol. 24, 195-205 (1989).

12. Bulmer, J.N. \& Lash, G.E. Human uterine natural killer cells: a reappraisal. Mol. Immunol. 42, 511-521. Review (2005).

13. Sentman, C.L., Wira, C.R. \& Eriksson, M. NK cell function in the human female reproductive tract. Am. J. Reprod. Immunol. 57, 108-115 (2007).

14. Basu, S., Pioli, P.A., Conejo-Garcia, J., Wira, C.R. \& Sentman, C.L. Estradiol regulates MICA expression in human endometrial cells. Clin. Immunol. 129, 325-332 (2008).

15. Mselle, T.F. et al. Unique characteristics of NK cells throughout the human female reproductive tract. Clin. Immunol. 124, 69-76 (2007).

16. Yeaman, G.R. et al. Unique CD8 + T cell rich lymphoid aggregates in human uterine endometrium. J. Leukoc. Biol. 61, 427-435 (1997).

17. Wira, C.R., Fahey, J.V., Ghosh, M., Patel, V., Hickey, D.K. \& Ochiel, D.O. Sex hormone regulation of innate immunity in the female reproductive tract: the role of epithelial cells in balancing reproductive potential with protection against sexually transmitted pathogens. Am. J. Reprod. Immunol. 63, 544-565 (2010).

18. Kawai, T. \& Akira, S. The role of pattern recognition receptors in innate immunity: update on Toll-like receptors. Nat. Immunol. 11, 373-384 (2010).

19. Philpott, D.J. \& Girardin, S.E. Nod-like receptors: sentinels at host membranes. Curr. Opin. Immunol. 22, 428-434 (2010).

20. Roan, N.R. \& Starnbach., M.N. Immune-mediated control of Chlamydia infection. Cell. Microbiol. 10, 9-19 (2008).

21. Agrawal, T., Vats, V., Salhan, S. \& Mittal, A. Determination of chlamydial load and immune parameters in asymptomatic, symptomatic and infertile women. FEMS Immunol. Med. Microbiol. 55, 250-257 (2009).

22. Bouman, A., Heineman, M.J. \& Faas, M.M. Sex hormones and the immune response in humans. Hum. Reprod. Update 11, 411-423 (2005).

23. Wira, C., Fahey, J., Wallace, P. \& Yeaman, G. Effect of the menstrual cycle on immunological parameters in the human female reproductive tract. J. Acquir. Immune Defic. Syndr. 38 (Suppl 1), S34-S36 (2005).

24. Kaldensjö, T., Petersson, P., Tolf, A., Morgan, G., Broliden, K. \& Hirbod, T. Detection of intraepithelial and stromal Langerin and CCR5 positive cells in the human endometrium: potential targets for HIV infection. PLOS One 6, e21344 (2011).

25. Hamad, M. The case for extrathymic development of vaginal $T$ lymphocytes. J. Reprod. Immunol. 77, 109-116 (2008).
26. Shaw, J.L. et al. Lymphoid and myeloid cell populations in the nonpregnant human fallopian tube and in ectopic pregnancy. J. Reprod. Immunol. 89, 84-91 (2011).

27. Dispep, B., Innes, B.A., Cochrane, H.R., Tijani, S. \& Bulmer, J.N. Immunohistochemical characterisation of endometrial leucocytes in endometritis. Histopathology 45, 625-632 (2004).

28. Ficarra, M. et al. A distinct cellular profile is seen in the human endocervix during Chlamydia trachomatis infection. Am. J. Reprod. Immunol. 60, 415-425 (2008).

29. Johansson, E.L., Rudin, A., Wassen, L. \& Holmgren, J. Distribution of lymphocytes and adhesion molecules in human cervix and vagina. Immunology 96, 272-277 (1999).

30. Kamat, B.R. \& Isaacson, P.G. The immunocytochemical distribution of leukocytic subpopulations in human endometrium. Am. J. Pathol. 127, 66-73 (1987).

31. Starkey, P.M., Clover, L.M. \& Rees, M.C. Variation during the menstrual cycle of immune cell populations in human endometrium. Eur. J. Obstet. Gynecol. Reprod. Biol. 39, 203-207 (1991).

32. Vassiliadou, N. \& Bulmer, J.N. Quantitative analysis of T lymphocyte subsets in pregnant and non-pregnant human endometrium. Biol. Reprod. 55, 1017-1022 (1996).

33. White, H.D. et al. CD3 + CD8 + CTL activity within the human female reproductive tract: influence of stage of the menstrual cycle and menopause. J. Immunol. 158, 3017-3027 (1997a).

34. Li, W., Yamamoto, H., Kubo, S. \& Okamura, H. Modulation of innate immunity by IL-18. J. Reprod. Immunol. 83, 101-105 (2009).

35. Agrawal, T., Vats, V., Wallace, P.K., Salhan, S. \& Mital, A. Role of cervical dendritic cell subsets, co-stimulatory molecules, cytokine secretion profile and beta-estradiol in development of sequalae to Chlamydia trachomatis infection. Reprod. Biol. Endocrinol. 6, 46-56 (2008).

36. White, H.D., Crassi, K. \& Wira, C.R. Cytolytic functional activities of NK cells and cytotoxic T lymphocytes (CTL) are coordinately regulated in the human female reproductive tract. In Cytolytic Functional Activities of NK cells and Cytotoxic T Lymphocytes (CTL) are Co-ordinately Regulated in the Human Female Reproductive (Tract, A.J. \& Husband, K.W. \& Beagley, R.L. \& Clancy, A.M. \& Collins, A.W. \& Cripps, D.L. \& Emery (eds)) pp 385-391 (The University of Sydney, Sydney, Australia, 1997).

37. Arrivito, L., Sanz, M., Banham, A.H. \& Fainboim, L. Expansion of CD4 + $\mathrm{CD} 25+$ and FOXP3 + regulatory T cells during the follicular phase of the menstrual cycle: implications for human reproduction. J. Immunol. 178, 2572-2578 (2007).

38. Tai, P. et al. Induction of regulatory T cells by physiological level estrogen. J. Cell. Physiol. 214, 456-464 (2008).

39. Marks, E., Tam, M.A. \& Lycke, N.Y. The female lower genital tract is a privileged compartment with IL-10 producing dendritic cells and poor Th1 immunity following Chlamydia trachomatis infection. PLoS Pathog. 6, e1001179 (2010).

40. Kelly, K.A., Wiley, D., Wiesmeier, E., Briskin, M., Butch, A. \& Darville, T. The combination of the gastrointestinal integrin $(\alpha 4 \beta 7)$ and selectin ligand enhances T-Cell migration to the reproductive tract during infection with Chlamydia trachomatis. Am. J. Reprod. Immunol. 61, 446-452 (2009).

41. Farage, M.A., Miller, K.W. \& Sobel, J.D. Dynamics of the vaginal ecosystem—hormonal influences. Infect. Dis. Res. Treat. 3, 1-15 (2010).

42. Cole, A.M. Innate host defense of human vaginal and cervical mucosae. Curr. Top. Microbiol. Immunol. 306, 199-230 (2006).

43. Wira, C.R. \& Fahey, J.V. The innate immune system: gatekeeper to the female reproductive tract. Immunology 111, 13-15 (2004).

44. Wira, C.R., Grant-Tschudy, K.S. \& Crane-Godreau, M.,A. Epithelial cells in the female reproductive tract: a central role as sentinels of immune protection. Am. J. Reprod. Immunol. 53, 65-76 (2005).

45. Horne, A.W., Stock, S.J. \& King, A.E. Epithelial cells in the female reproductive tract: a central role as sentinels of immune protection. Reprod. J. 135, 739-749 (2008).

46. Ochiel, D.O., Fahey, J.V., Ghosh, M., Haddad, S.N. \& Wira, C.R. Innate immunity in th female reproductive tract: role of sex hormones in regulating uterine epithelial cell protection against pathogens. Curr. Womens Health Rev. 4, 102-117 (2008).

47. Kaushic, C. The role of the local microenvironment in regulating susceptibility and immune responses to sexually transmitted viruses in the female genital tract. J. Reprod. Immunol. 83, 168-172 (2009). 
48. Rakasz, E.Z. \& Lynch, R.G. Female sex hormones as regulatory factors in the vaginal immune compartment. Intern. Rev. Immunol. 21, 497-513 (2002).

49. Butts, C.L. et al. Inhibitory effects of progesterone differ in dendritic cells from female and male rodents. Gender Med. 5, 434-447 (2008).

50. Fish, E.N. The X-files in immunity: sex-based differences predispose immune responses. Nat. Rev. Immunol. 8, 737-744 (2008).

51. Karpuzoglu, E. \& Ahmed, S.A. Estrogen regulation of nitric oxide and inducible nitric oxide synthase (iNOS) in immune cells: implications for immunity, autoimmune diseases, and apoptosis. Nitric Oxide 15, 177-186 (2006).

52. Verthelyi, D. Female's heightened immune status: estrogen, T cells, and inducible nitric oxide synthase in the balance. Endocrinology 147, 659-661 (2006).

53. Butts, C.L. \& Sternberg, E.M. Neuroendocrine factors alter host defense by modulating immune function. Cell. Immunol. 252, 7-15 (2008).

54. Aflatoonian, R. et al. Menstrual cycle-dependent changes of Toll-like receptors in endometrium. Hum. Reprod. 22, 586-593 (2007).

55. Aflatoonian, R. \& Fazeli, A. Toll-like receptors in female reproductive tract and their menstrual cycle dependent expression. J. Reprod. Immunol. 77, 7-13 (2008).

56. Hemmi, H. et al. Toll-like receptor recognizes bacterial DNA. Nature 408, 740-745 (2000).

57. Sheldon, I.M. \& Bromfield, J.J. Innate immunity in the human endometrium and ovary. Am. J. Reprod. Immunol. 66 (Suppl 1), 63-71 (2011).

58. Rodriguez-Garcia, M., Patel, M.V. \& Wira, C.R. Innate and adaptive antiHIV immune responses in the female reproductive tract. J. Reprod. Immunol. 97, 74-84 (2013).

59. Wira, C.R., Fahey, J.V., Sentman, C.L., Pioli, P.A. \& Shen, L. Innate and adaptive immunity in female genital tract: cellular responses and interactions. Immunol. Rev. 206, 306-335 (2005).

60. King, A.E., Critchley, H.O.D. \& Kelly, R.W. Innate immune defences in the human endometrium. Reprod. Biol. Endocrinol. 1, 116-124 (2003).

61. Fahey, J.V., Rossoll, R.M. \& Wira, C.R. Sex hormone regulation of anti-bacterial activity in rat uterine secretions and apical release of anti-bacterial factor(s) by uterine epithelial cells in culture. J. Steroid Biochem. Mol. Biol. 93, 59-66 (2005).

62. King, A.E. et al. Expression of secretory leukocyte protease inhibitor and elafin in human fallopian tube and in an in-vitro model of Chlamydia trachomatis infection. Hum. Reprod. 24, 679-686 (2009).

63. Kumar, H., Kawai, T. \& Akira, S. Pathogen recognition by the innate immune system. Int. Rev. Immunol. 30, 16-34 (2011).

64. Hart, K.M., Murphy, A.J., Barrett, K.T., Wira, C.R., Guyre, P.M. \& Pioli, P.A. Functional expression pattern recognition receptors in tissues of thye human female reproductive tract. J. Reprod. Immunol. 80, 33-40 (2009).

65. Aflatoonian, R. et al. Expression of Toll-like receptors in endometrium during the menstrual cycle. J. Reprod. Immunol. 71, 152 (2006).

66. Fichorova, R.N., Cronin, A.O., Lien, E., Anderson, D.J. \& Ingalls, R.R. Response to Neisseria gonorrhoeae by cervicovaginal epithelial cells occurs in the absence of toll-like receptor 4-mediated signaling. J. Immunol. 168, 2424-2432 (2002).

67. Andersen, J.M., Al-Khairy, D. \& Ingalls, R.R. Innate immunity at the mucosal surface: role of toll-like receptor 3 and toll-like receptor 9 in cervical epithelial cell responses to microbial pathogens. Biol. Reprod. 74, 824-831 (2006).

68. Beagley, K.W. \& Gockel, C.M. Regulation of innate and adaptive immunity by the female sex hormones oestradiol and progesterone. FEMS Immunol. Med. Microbiol. 38, 13-22 (2003).

69. Fung, K.Y. et al. Interferon- $\varepsilon$ protects the female reproductive tract from viral and bacterial infection. Science 339, 1088-1092 (2013).

70. Smith, J.M., Shen, Z., Wira, C.R., Fanger, M.W. \& Shen, L. Effects of menstrual cycle status and gender on human neutrophil phenotype. Am. J. Reprod. Immunol. 58, 111-119 (2007).

71. Schulke, L., Manconi, F., Markham, R. \& Fraser, I.S. Endometrial dendritic cell populations during the normal menstrual cycle. Hum. Reprod. 23, 1574-1580 (2008).

72. Heine, H., Müller-Loennies, S., Brade, L., Lindner, B. \& Brade, H. Endotoxic activity and chemical structure of lipopolysaccharides from Chlamydia trachomatis serotypes E and L2 and Chlamydophila psittaci 6BC. Eur. J. Biochem. 270, 440-450 (2003).
73. Da Costa, C.U. et al. Heat shock protein 60 from Chlamydia pneumoniae elicits an unusual set of inflammatory responses via Toll-like receptor 2 and 4 in vivo. Eur. J. Immunol. 34, 2874-2884 (2004).

74. Derbigny, W.A., Kerr, M.S. \& Johnson, R.M. Pattern recognition molecules activated by Chlamydia muridarum infection of cloned murine oviduct epithelial cell lines. J. Immunol. 175, 6065-6075 (2005).

75. Vabulas, R.M. et al. Endocytosed HSP60s use toll-like receptor 2 (TLR2) and TLR4 to activate the toll/interleukin-1 receptor signaling pathway in innate immune cells. J. Biol. Chem. 276, 31332-31339 (2001).

76. Prebeck, S. et al. Predominant role of toll-like receptor 2 versus 4 in Chlamydia pneumoniae-induced activation of dendritic cells. J. Immunol. 167, 3316-3323 (2001)

77. Welter-Stahl, L. et al. Stimulation of the cytosolic receptor for peptidoglycan, Nod1, by infection with Chlamydia trachomatis or Chlamydia muridarum. Cell. Microbiol. 8, 1047-1057 (2006).

78. Mauck, C.K. et al. The effect of one injection of Depo-Provera on the human vaginal epithelium and cervical ectopy. Contraception 60, 15-24 (1999).

79. Morrison, S.G., Farris, C.M., Sturdevant, G.L., Whitmire, W.M. \& Morrison, R.P. Murine Chlamydia trachomatis genital infection is unaltered by depletion of CD4 + Tcells and diminished adaptive immunity. J. Infect. Dis. 203, 1120-1128 (2011).

80. Prabhala, R.H. \& Wira, C.R. Sex hormone and IL-6 regulation of antigen presentation in the female reproductive tract mucosal tissues. J. Immunol. 155, 5566-5573 (1995).

81. Wira, C.R. \& Rossoll, R.M. Antigen-presenting cells in the female reproductive tract: influence of sex hormones on antigen presentation in the vagina. Immunology 84, 505-508 (1995).

82. Fahey, J.V., Prabhala, R.H., Guyre, P.M. \& Wira, C.R. Antigen-presenting cells in the human female reproductive tract: analysis of antigen presentation in pre- and post-menopausal women. Am. J. Reprod. Immunol. 42, 49-57 (1999).

83. Wallace, P.K., Yeaman, G.R., Johnson, K., Collins, J.E., Guyre, P.M. \& Wira, C.R. MHC class II expression and antigen presentation by human endometrial cells. J. Steroid Biochem. Mol. Biol. 76, 203-211 (2001).

84. Cella, M., Scheidegger, D., Palmer-Lehmann, K., Lane, P., Lanzavecchia, A. \& Alber, G. Ligation of CD40 on dendritic cells triggers production of high levels of interleukin-12 and enhances T cell stimulatory capacity: T-T help via APC activation. J. Exp. Med. 184, 747-752 (1996).

85. Macatonia, S.E. et al. Dendritic cells produce $\mathrm{IL}-12$ and direct the development of Th1 cells from naive CD4 + T cells. J. Immunol. 154, 5071-5079 (1995).

86. Bengtsson, A.K., Ryan, E.J., Giordano, D., Magaletti, D.M. \& Clark, E.A. 17beta-estradiol (E2) modulates cytokine and chemokine expression in human monocyte-derived dendritic cells. Blood 104, 1404-1410 (2004).

87. Nalbandian, G. \& Kovats, S. Understanding sex biases in immunity. Immunol. Res. 31, 91-106 (2005).

88. Butts, C.L. \& Sternberg, E.M. Neuroendocrine factors alter host defense by modulating immune function. Cell. Immunol. 252, 7-15 (2008).

89. Hughes, G.C. \& Clark, E.A. Regulation of dendritic cells by female sex steroids: relevance to immunity and autoimmunity. Autoimmunity 40, 470-481 (2007).

90. Kovats, S. \& Carreras, E. Regulation of dendritic cell differentiation and function by estrogen receptor ligands. Cell. Immunol. 252, 81-90 (2008).

91. Douin-Echinard, V. et al. Estrogen receptor alpha, but not beta,is required for optimal dendritic cell differentiation and CD40-induced cytokine production. J. Immunol. 180, 3661-3669 (2008).

92. Uemura, Y., Liu, T.Y., Narita, Y., Suzuki, M. \& Matsushita, S. 17 Beta-estradiol (E2) plus tumor necrosis factor-alpha induces a distorted maturation of human monocyte-derived dendritic cells and promotes their capacity to initiate T-helper 2 responses. Hum. Immunol. 69, 149-157 (2008).

93. Liang, J., Sun, L., Wang, Q. \& Hou, Y. Progersterone regulates mouse dendritic cells differentiation and maturation. Int. Immunopharmacol. 6, 830-838 (2006).

94. Weaver, C., Harrington, L., Managan, P., Gavrieli, M. \& Murphy, K. Th17: An effector CD4 cell lineage with regulatory $T$ cell ties. Immunity 24, 677-688 (2006) 
95. lijima, N., Thompson, J.M. \& Iwasaki, A. Dendritic cells and macrophages in the genitourinary tract. Mucosal Immunol. 1, 451-469 (2008).

96. Keenihan, S.N. \& Roberston, A.A. Diversity in phenotype and steroid hormone dependence in dendritic cells and macrophages in the mouse uterus. Biol. Reprod. 70, 1562-1572 (2004).

97. Sajic, D., Patrick, A.J. \& Rosenthal, K.L. Mucosal delivery of CpG oligodeoxynucleotides expands functional dendritic cells and macrophages in the vagina. Immunology 114, 213-224 (2005).

98. Patton, D.L., Thinn, S.S., Meier, A., Hooton, T.M., Stapleton, A.E. \& Eschenbach, D.A. Epithelial cell layer thickness and immune cell populations in the normal human vagina at different stages of the menstrual cycle. Am. J. Obstet. Gynecol. 183, 967-973 (2000).

99. Kaul, R. et al. The genital tract immune milieu: an important determinant of HIV susceptibility and secondary transmission. J. Reprod. Immunol. 77, 32-40 (2008).

100. Kramer, P.R., Winger, V. \& Kramer, S.F. 17B-estradiol utilizes the estrogen receptor to regulate CD16 expression in monocytes. Mol. Cell. Endocrinol. 279, 16-25 (2007).

101. Murphy, A.J., Guyre, P.M., Wira, C.R. \& Pioli, P.A. Estradiol regulates expression of estrogen receptor ERa46 in human macrophages. PLoS One 4, 1-11 (2009).

102. Rettew, J.A., Huet, Y.M. \& Marriott, I. Estrogens augment cell surface TLR4 expression on murin macrophages and regulate sepsis susceptibility in vivo. Endocrinology 50, 3877-3884 (2009).

103. Su, L., Sun, Y., Ma, F., Lü, P., Huang, H. \& Zhou, J. Progesterone inhibits Toll-like receptor 4-mediated innate immune response in macrophages by suppressing NF-kappaB activation and enhancing SOCS1 expression. Immunol. Lett. 125, 151-155 (2009).

104. Grant-Tschudy, K.S. \& Wira, C.R. Effect of oestradiol on mouse uterine epithelial cell tumour necrosis factor-a release is mediated through uterine stromal cells. Immunology 115, 99-107 (2005).

105. Suzuki, S., Brown, C., Dela Cruz, C.D., Yang, E., Bridwell, D.A. \& Wise, P.M. Timing of estrogen therapy after ovariectomy dictates the efficacy of its neuroprotective and antiinflammatroy actions. PNAS 104, 6013-6018 (2007).

106. Wira, C.R., Fahey, J.V., Sentman, C.L., Pioli, P.A. \& Shen, L. Innate and adaptive immunity in female genital tract: cellular responses and interactions. Immunol. Rev. 206, 306-335 (2005).

107. Lesmeister, M.J., Jorgensen, R.L., Young, S.L. \& Misfeldt, M.L. 17 betaestradiol suppresses TLR3-induced cytokine and chemokine production in endometrial epithelial cells. Reprod. Biol. Endocrinol. 3, 74-89 (2005).

108. Yang, D. et al. Many chemokines including CCL20/MIP-3alpha display antimicrobial activity. J. Leukoc. Biol. 74, 448-455 (2003).

109. Baba, M. et al. Identification of CCR6, the specific receptor for a novel lymphocyte-directed CC chemokine LARC. J. Biol. Chem. 272, 14893-14898 (1997).

110. Sun, B., Nasu, K., Fukuda, J., Mine, S., Nishida, M. \& Miyakawa, I. Expression of macrophage inflammatory protein-3alpha in an endometrial epithelial cell line, HHUA, and cultured human endometrial stromal cells. Mol. Hum. Reprod. 8, 930-933 (2002).

111. Saenz, S.A., Taylor, B.C. \& Artis, D. Welcome to the neighborhood: epithelial cell-derived cytokines license innate and adaptive immune responses at mucosal sites. Immunol. Rev. 226, 172-190 (2008).

112. Han, G., Magee, T. \& Khorram, O. Regulation of nitric oxide synthases isoforms by estrogen in the human endometrium. Fertil. Steril. 84, 1220-1227 (2005).

113. Khorram, O. \& Han, G. Influence of progesterone on endometrial nitric oxide syhtnase expression. Fertil. Steril. 91, 2157-2162 (2009).

114. Neutra, M.R., Pringault, E. \& Kraehenbuhl, J.P. Antigen sampling across epithelial barriers and induction of mucosal immune responses. Annu. Rev. Immunol. 14, 275-300 (1996).

115. Miller, C.J., McChesney, M. \& Moore, P.F. Langerhans cells, macrophages and lymphocyte subsets in the cervix and vagina of rhesus macaques. Lab. Invest. 67, 628-634 (1992).

116. Kelly, K.A. T-lymphocyte trafficking to the female reproductive tract mucosae. [book auth.]. In Chlamydia: Genomics and Pathogenesis (Wyrick,, P.B., eds)) 413-435 ((Horizon Bioscience, Norfolk, UK, 2006).

117. Kelly, K.A., Walker, J.C., Jameel, S.H., Gray, H.L. \& Rank, R.G. Differential regulation of CD4 lymphocyte recruitment between the upper and lower regions of the genital tract during Chlamydia trachomatis infection. Infect. Immun. 68, 1519-1528 (2000).

118. Maxion, H.K. \& Kelly, K.A. Chemokine expression patterns differ within anatomically distinct regions of the genital tract during Chlamydia trachomatis infection. Infect. Immun. 70, 1538-1546 (2002).

119. Johansson, M. \& Lycke, N. A unique population of extrathymically derived alhabetaTCR + CD4-CD8- T cells with regulatory functions dominates the mouse female genital tract. J. Immunol. 170, 1659-1666 (2003).

120. Lopez, M.C. \& Stanley, M.A. Cytokine profile of mouse vaginal and uterus lymphocytes at estrus and diestrus. Clin. Dev. Immunol. 12, 159-164 (2005).

121. Polanczyk, M.J., Hopke, C., Vandenbark, A.A. \& Offner, H. Estrogenmediated immunomodulation involves reduced activation of effector $T$ cells, potentaition of Treg cells and enhanced expression of the PD-1 costimulatory pathway. J. Neurosci. Res. 84, 370-378 (2006).

122. Polanczyk, M.J., Hopke, C., Vandenbark, A.A. \& Offner, H. Treg suppressive activity involves estrogen-dependent expression of programmed death-1 (PD-1). Int. Immunol. 19, 337-343 (2007).

123. Weinberg, A., Enomoto, L., Marcus, R. \& Canniff, J. Effect of menstrual cycle variation in female sex hormones on cellular immunity and regulation. J. Reprod. Immunol. 89, 70-77 (2011).

124. Witkiewicz, A.K., McConnell, T., Potoczek, M., Emmons, R.V. \& Kurman, R.J. Increased natural killer cells and decreased regulatory Tcells are seen in complex atypical endometrial hyperplasia and well-differentiated carcinoma treated with progestins. Hum. Pathol. 41, 26-32 (2010).

125. Mjösberg, J. et al. Systemic reduction of functionally suppressive CD4dimCD25highFoxp3 + Tregs in human second trimester pregnancy is induced by progesterone and 17beta-estradiol. J. Immunol. 183, 759-769 (2009).

126. Ku, L.T., Gercel-Taylor, C., Nakajima, S.T. \& Taylor, D.D. Alterations fTcell activation signalling and cytokine production by postmenopausal estrogen levels. Immun. Ageing 6, 1-12 (2009).

127. Rank, R.G., Sanders, M.M. \& Kidd, A.T. Influence of the estrous cycle on the development of upper genital tract pathology as a result of chlamydial infection in the guinea pig model of pelvic inflammatory disease. Am. J. Pathol. 142, 1291-1296 (1993).

128. Pasley, J.N., Rank, R.G., Hough, A.J. Jr, Cohen, C. \& Barron, A.L. Absence of progesterone effects on chlamydial genital infection in female guinea pigs. Sex Transm. Dis. 12, 155-158 (1985).

129. Mestecky, J., Moldoveneau, Z. \& Russell, M.W. Immunologic uniqueness of the genital tract: challenges for vaccine development. Am. J. Reprod. Immunol. 53, 208-214 (2005).

130. Russell, M.W. \& Mestecky, J. Humoral immune responses to microbial infections in the genital tract. Microbes Infect. 4, 667-677 (2002).

131. Li, Z., Palaniyandi, S., Zeng, R., Tuo, W., Roopenian, D.C. \& Zhu, X. Transfer of IgG in the female genital tract by MHC class I-related neonatal Fc receptor ( $\mathrm{FCRn}$ ) confers protective immunity to vaginal infection. Proc. Natl. Acad. Sci. USA 108, 4388-4393 (2011).

132. Wang, Y., Ben, K., Cao, X. \& Wang, Y. Transport of anti-sperm monoclonal $\mathrm{IgA}$ and IgG into murine male and female genital tracts from blood: Effect of sex hormones. J. Immunol. 156, 1014-1019 (1996).

133. Cha, H.R. et al. Mucosa-associated epithelial chemokine/CCL28 expression in the uterus attracts CCR10 + IgA plasma cells following mucosal vaccination via estrogen control. J. Immunol. 187, 3044-3052 (2011).

134. Menge, A.C. \& Mestecky, J. Surface expression of secretory component and HLA class II DR antigen on glandular epithelial cells from human endometrium and two endometrial adenocarcinoma cell lines. J. Clin. Immunol. 13, 259-264 (1993).

135. Nardelli-Haefliger, D.J. et al. Specific antibody levels at the cervix during the menstrual cycle of women vaccinated with human papillomavirus 16 virus-like particles. J. Natl. Cancer Inst. 95, 1128-1147 (2003).

136. Shrier, L.A., Bowman, F.P., Lin, M. \& Crowley-Nowick, P.A. Mucosal immunity of the adolescent female genital tract. J. Adolesc. Health $\mathbf{3 2}$, 183-186 (2003).

137. Lu, F.X. et al. The strength of B cell immunity in female rhesus macaques is controlled by $\mathrm{CD} 8+\mathrm{T}$ cells under the influence of ovarain steroid hormones. Clin. Exp. Immunol. 128, 10-20 (2002).

138. Lu, F.X., Ma, Z., Moser, S., Evans, T.G. \& Miller, C.J. Effects of ovarian steroids on immunoglobulin-secreting cell function in healthy women. Clin. Diag. Lab. Immunol. 10, 944-949 (2003). 
139. Lamason, R. et al. Sexual dimorphism in immune response genes as a function of puberty. BMC Immunol. 7, 2 (2006).

140. Ding, J. \& Zhu, B.T. Unique effect of the pregnancy hormone estriol on antigen-induced production of specific antibodies in female BALB/C mice. Steroids 73, 289-298 (2008).

141. Yu, M., Cao, X., Wang, X., Xu, J., Yang, M. \& Ben, K. Migration of mouse antibody-secreting hybridoma cells from blodd to genital tract and its regulation by sex hormones are associated with the differential expression patterns of adhesion molecules and chemokines in the tract rather than antibody-secreting. J. Reprod. Immunol. 74, 78-89 (2007).

142. Grimaldi, C.M., Hill, L., Xu, X., Peeva, E. \& Diamond, B. Hormonal modulation of $\mathrm{B}$ cell development and repetoire selection. Mol. Immunol. 42, 811-820 (2005).

143. Lagerquist, M.K., Erlandsson, M.C., Islander, U., Svensson, L., Holmdahl, R. \& Carlston, H. 17b-estradiol expands IgA-producing $\mathrm{B}$ cells in mice deficient for the $\mathrm{u}$ chain. Scand. J. Immunol. 67 12-17 (2007).

144. Wright, A., Yan, H., Lamm, M.,E. \& Huang, Y.T. Immunoglobulin A antibodies against internal HIV-1 proteins neutralise HIV-1 replication inside epithelial cells. Virology 356, 165-170 (2006).

145. Kaushic, C., Frauendorf, E. \& Wira, C.R. Polymeric immunoglobulin A receptor in the rodent female reproductive tract: influence of estradiol in the vagina and differential expression of messenger ribonucleic acid during estrous cycle. Biol. Reprod. 57, 958-966 (1997).

146. Mestecky, J. \& Lamm, M.E. \& Strober, W. \& Bienenstock, J. \& McGhee, J.R. \& Mayer, L., (eds). Mucosal Immunology. Elsevier, Oxford, UK, 2005).

147. Wira, C.R. \& Sullivan, D.A. Estradiol and progesterone regualtion of immunoglobulinA and $\mathrm{G}$ and secretory component in the cervicovaginal secretions of the rat. Biol. Reprod. 32, 90-95 (1985).

148. Hel, Z., Stringer, E. \& Mestecky, J. Sex steroid hormones, hormona contraception and the immunobiology of human immunodeficiency virus1 infection. Endocr. Rev. 31, 79-97 (2010).

149. Draper, D.L., Landers, D.V., Krohn, M.A., Hillier, S.L., Weisenfeld, H.C. \& Heine, R.P. Levels of vaginal secretory leukocyte protease inhibitor are decreased in women with lower reproductive tract infections. Am. J. Obstet. Gynecol. 183, 1243-1248 (2000).

150. Wheelhouse, N., Wattegedera, S., Fleming, D., Fitch, P., Kelly, R. \& Entrican, G. Chlamydia trachomatis and Chlamydophila abortus induce the expression of secretory leukocyte protease inhibitor in cells of the human female reproductive tract. Microbiol. Immunol. 52, 465-468 (2008).

151. Pal, S., Schmidt, A.P., Peterson, E.M., Wilson, C.L. \& de la Maza, L.M. Role of matrix metalloproteinase- 7 in the modulation of a Chlamydia trachomatis infection. Immunology 117, 213-219 (2006).

152. Oberley, R.E., Goss, K.L., Ault, K.A., Crouch, E.C. \& Snyder, J.M. Surfactant protein $D$ is present in the human female reproductive tract and inhibits Chlamydia trachomatis infection. Mol. Hum. Reprod. 10, 861-870 (2004).

153. Yasin, B., Pang, M., Wagar, E.A. \& Lehrer, R.I. Examination of Chlamydia trachomatis infection in environments mimicking normal and abnormal vaginal pH. Sex Transm. Dis. 29, 514-519 (2002).

154. O'Connell, C.M., Ionova, I.A., Quayle, A.J., Visintin, A. \& Ingalls, R.R. Localization of TLR2 and MyD88 to Chlamydia trachomatis inclusions. Evidence for signaling by intracellular TLR2 during infection with an obligate intracellular pathogen. J. Biol. Chem. 281, 1652-1659 (2006).

155. O'Connell, C.M., Ingalls, R.R., Andrews, C.W. Jr, Scurlock, A.M. \& Darville, T. Plasmid-deficient Chlamydia muridarum fail to induce immune pathology and protect against oviduct disease. J. Immunol. 179, 4027-4034 (2007)

156. O'Connell, C.M. et al. Toll-like receptor 2 activation by Chlamydia trachomatis is plasmid dependent, and plasmid-responsive chromosomal loci are coordinately regulated in response to glucose limitation by $C$. trachomatis but not by C. muridarum. Infect. Immun. 79, 1044-1056 (2011).

157. Darville, T. \& Hiltke, T.J. Pathogenesis of genital tract disease due to Chlamydia trachomatis. J. Infect. Dis. 201 (Suppl 2), S114-S125 (2010).

158. Schaefer, T.M., Desouza, K., Fahey, J.V., Beagley, K.W. \& Wira, C.R. Toll-like receptor (TLR) expression and TLR-mediated cytokine/ chemokine production by human uterine epithelial cells. Immunology 112, 428-436 (2004).
159. Pioli, P.A., Amiel, E., Schaefer, T.M., Connolly, J.E., Wira, C.R. \& Guyre, P.M. Differential expression of Toll-like receptors 2 and 4 in tissues of the human female reproductive tract. Infect. Immun. 72, 5799-5806 (2004).

160. Fazeli, A., Bruce, C. \& Anumba, D.O. Characterization of Toll-like receptors in the female reproductive tract in humans. Hum. Reprod. 20, 1372-1378 (2005).

161. Agrawal, T., Bhengraj, A.R., Vats, V., Salhan, S. \& Mittal, A. Expression of TLR 2, TLR 4 and iNOS in cervical monocytes of Chlamydia trachomatisinfected women and their role in host immune response. Am. J. Reprod. Immunol. 66, 534-543 (2011).

162. Mahmoud, E.A., Hamad, E.E., Olsson, S.E. \& Mårdh, P.A. Anti-chlamydial activity of cervical secretion in different phases of the menstrual cycle and influence of hormonal contraceptives. Contraception 49, 265-274 (1994).

163. Sweet, R.L., Landers, D.V., Walker, C. \& Schachter, J. Chlamydia trachomatis infection and pregnancy outcome. Am. J. Obstet. Gynecol. 156, 824-833 (1987).

164. Olive, A.J., Gondek, G.C. \& Starnbach, M.N. CXCR3 and CCR5 are both required for T-cell mediated protection against $C$. trachomatis infection in the murine genital mucosa. Mucosal Immunol 4, 208-216 (2011).

165. Agrawal, T., Vats, V., Wallace, P.K., Salhan, S. \& Mittal, A. Cervical cytokine reponses in women with primary or recurrent chlamydial infection. J. Interferon Cytokine Res. 27, 221-226 (2007).

166. Pal, S., Hui, W., Peterson, E.M. \& de la Maza, L.M. Factors influencing the induction of infertility in a mouse model of Chlamydia trachomatis ascending genital tract infection. J. Med. Microbiol. 47, 599-605 (1998).

167. Kaushic, C., Zhou, F., Murdin, A.D. \& Wira, C.R. Effects of estradiol and progesterone on susceptibility and early immune responses to Chlamydia trachomatis infection in the female reproductive tract. Infect. Immun. 68, 4207-4216 (2000).

168. Darville, T., Andrews, C.W. Jr, Laffoon, K.K., Shymasani, W., Kishen, L.R. \& Rank, R.G. Mouse strain-dependent variation in the course and outcome of chlamydial genital tract infection is associated with differences in host response. Infect. Immun. 65, 3065-3073 (1997).

169. Bose, S.K. \& Goswami, P.C. Enhancement of adherence and growth of Chlamydia trachomatis by estrogen treatment of HeLa cells. Infect. Immun. 53, 646-650 (1986).

170. Davis, C.H., Raulston, J.E. \& Wyrick, P.B. Protein disulfide isomerase, a component of the estrogen receptor complex, is associated with Chlamydia trachomatis serovar E attached to human endometrial epithelial cells. Infect. Immun. 70, 3413-3418 (2002).

171. Guseva, N.V., Knight, S.T., Whittimore, J.D. \& Wyrick, P.B. Primary cultures of female swine genital epithelail cells in vitro: a new approach for the study of hormonal modulation of chlamydial infection. Infect. Immun. 71, 4700-4710 (2003).

172. Guseva, N.V., Dessus- Babus, S.C., Whittimore, J.D., Moore, C.G. \& Wyrick, P.B. Characterization of estrogen-responsive epithelial cell lines and their infectivity by genital Chlamydia trachomatis. Microbes Infect. 7 , 1469-1481 (2005).

173. Maslow, A.S., Davis, C.H., Choong, J. \& Wyrick, P.B. Estrogen enhances attachment of Chlamydia trachomatis to human endometrial epithelial cells in vitro. Am. J. Obstet. Gynecol. 159, 1006-1014 (1988).

174. Wyrick, P.B., Davis, C.H., Knight, S.T., Choong, J., Raulston, J.E. \& Schramm, N. An in vitro human epithelial cell culture system for studying the pathogenesis of Chlamydia trachomatis. Sex Transm. Dis. 20, 248-256 (1993).

175. Amirshahi, A., Wan, C., Beagley, K., Latter, J., Symonds, I. \& Timms, P. Modulation of the Chlamydia trachomatis in vitro transcriptome response by the sex hormones estradiol and progesterone. BMC Microbiol. 11, 150 (2011).

176. Morrison, C.S. et al. Hormonal contraceptive use, cervical ectopy, and the acquisition of cervical infections. Sex Transm. Dis. 2004)31, 561-567 (2004)

177. Dayan, L. \& Donovan, B. Chlamydia, gonorrhoea, and injectable progesterone. Lancet 364, 1387-1388 (2004).

178. Hubacher, D. et al. Hormonal contraception and the risks of ST acquisition: results of a feasibility study to plan a future randomized trial. Contraception 77, 366-370 (2008).

179. Gockel, C.M., Bao, S., Holland, M.K. \& Beagley, K.W. Influence of the murine oestrous cycle on induction of mucosal immunity. Am. J. Reprod. Immunol. 50, 369-379 (2003). 
180. Seavey, M.M. \& Mosmann, T.R. Estradiol-induced vaginal mucus inhibits antigen penetration and $\mathrm{CD} 8(+)$ Tcell priming in response to intravaginal immunization. Vaccine 27, 2342-2349 (2009).

181. Song, W. et al. Local and humoral immune responses against primary and repeat Neisseria. Vaccine 26, 5741-5751 (2008).

182. Li, J. \& McMurray, R.W. Effects of estrogen receptor subtype-selective agonists on immune functions in ovariectomized mice. Int. Immunopharmacol. 6, 1413-1423 (2006).

183. Marks, E., Helgeby, A., Andersson, J.O., Schon, K. \& Lycke, N.Y. CD4 + T-cell immunity in the female genital tract is critically dependent on local mucosal immunization. Eur. J. Immunol. 41, 2642-2653 (2011).
184. Abel, K., Rourke, T., Lu, D., Bost, K., McChesney, M.B. \& Miller, C.J. Abrogation of attenuated lentivirus-induced protection in rhesus macaques by administration of depo-provera before intravaginal challenge with simian immunodeficiency virus mac239. J. Infect. Dis. 190, 1697-1705 (2004).

185. Wassen, L. \& Jetborn, M. Influence of exogenous reproductive hormones on specific antibody production in genital secretions after vaginal vaccination with recombinant cholera toxin $\mathrm{B}$ subunit in humans. Clin. Vaccine Immunol. 13, 202-207 (2006).

186. Kozlowski, P.A. et al. Differential induction of mucosal ans systemic antobody responses in women after nasal, rectal or aginal immunization: influence of the menstrual cycle. J. Immunol. 169, 566-574 (2002). 